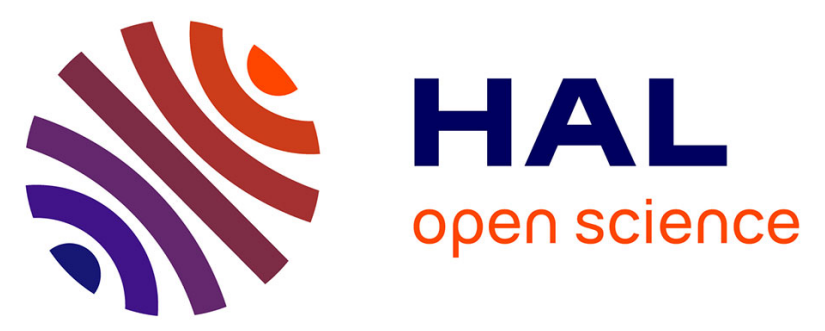

\title{
The Ikaria high-temperature Metamorphic Core Complex (Cyclades, Greece): Geometry, kinematics and thermal structure
}

\author{
Alexandre Beaudoin, Romain Augier, Valentin Laurent, Laurent Jolivet, \\ Abdeltif Lahfid, Valérie Bosse, Laurent Arbaret, Aurélien Rabillard, Armel \\ Menant
}

\section{To cite this version:}

Alexandre Beaudoin, Romain Augier, Valentin Laurent, Laurent Jolivet, Abdeltif Lahfid, et al.. The Ikaria high-temperature Metamorphic Core Complex (Cyclades, Greece): Geometry, kinematics and thermal structure. Journal of Geodynamics, 2015, 92, pp.18-41. 10.1016/j.jog.2015.09.004 . insu01225362

\section{HAL Id: insu-01225362 \\ https://hal-insu.archives-ouvertes.fr/insu-01225362}

Submitted on 6 Nov 2015

HAL is a multi-disciplinary open access archive for the deposit and dissemination of scientific research documents, whether they are published or not. The documents may come from teaching and research institutions in France or abroad, or from public or private research centers.
L'archive ouverte pluridisciplinaire HAL, est destinée au dépôt et à la diffusion de documents scientifiques de niveau recherche, publiés ou non, émanant des établissements d'enseignement et de recherche français ou étrangers, des laboratoires publics ou privés.

\section{(ㄷ)(1) $\Theta$}

Distributed under a Creative Commons Attribution - NoDerivatives| 4.0 International 


\section{Accepted Manuscript}

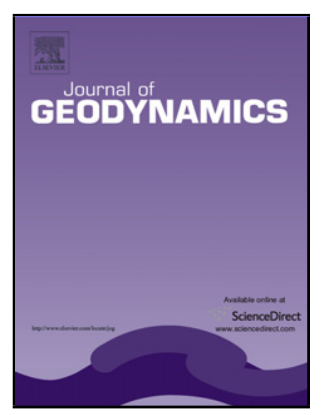

Author: Alexandre Beaudoin Romain Augier Valentin

Laurent Laurent Jolivet Abdeltif Lahfid Valérie Bosse Laurent

Arbaret Aurélien Rabillard Armel Menant

PII:

S0264-3707(15)30025-9

DOI: http://dx.doi.org/doi:10.1016/j.jog.2015.09.004

Reference:

GEOD 1390

To appear in: $\quad$ Journal of Geodynamics

Received date: $\quad$ 29-1-2015

Revised date: $\quad 18-9-2015$

Accepted date: $\quad$ 28-9-2015

Please cite this article as: Beaudoin, A., Augier, R., Laurent, V., Jolivet, L., Lahfid, A., Bosse, V., Arbaret, L., Rabillard, A., Menant, A.,The Ikaria high-temperature Metamorphic Core Complex (Cyclades, Greece): Geometry, kinematics and thermal structure, Journal of Geodynamics (2015), http://dx.doi.org/10.1016/j.jog.2015.09.004

This is a PDF file of an unedited manuscript that has been accepted for publication. As a service to our customers we are providing this early version of the manuscript. The manuscript will undergo copyediting, typesetting, and review of the resulting proof before it is published in its final form. Please note that during the production process errors may be discovered which could affect the content, and all legal disclaimers that apply to the journal pertain. 
Ikaria Island corresponds to a large-scale migmatite-cored MCC.

Thermal structure revealed by RSCM shows a drastic increase from top to bottom.

The MCC was exhumed by two detachments through the brittle-ductile transition.

Migmatites were dated to $15.7 \pm 2 \mathrm{Ma}$ by $\mathrm{U}$-Th- $\mathrm{Pb}$ analysis on monazites.

A large-scale high temperature zone is proposed for the central part of the Aegean. 
1 The Ikaria high-temperature Metamorphic Core Complex (Cyclades, Greece): Geometry,

2 kinematics and thermal structure.

3

4 Alexandre Beaudoin ${ }^{\mathrm{a}, \mathrm{b}, \mathrm{c}, *}$, Romain Augier $^{\mathrm{a}, \mathrm{b}, \mathrm{c}}$, Valentin Laurent ${ }^{\mathrm{a}, \mathrm{b}, \mathrm{c}}$, Laurent Jolivet ${ }^{\mathrm{a}, \mathrm{b}, \mathrm{c}}$, 5 Abdeltif Lahfid ${ }^{\mathrm{b}, \mathrm{c}}$, Valérie Bosse ${ }^{\mathrm{d}}$, Laurent Arbaret $^{\mathrm{a}, \mathrm{b}, \mathrm{c}}$, Aurélien Rabillard ${ }^{\mathrm{a}, \mathrm{b}, \mathrm{c}}$, Armel 6 Menant $^{\mathrm{a}, \mathrm{b}, \mathrm{c}}$

7

$8 \quad$ a'Université d'Orléans, ISTO, UMR 7327, 45071, Orléans, France

$9 \quad{ }^{\mathrm{b}} \mathrm{CNRS} / \mathrm{INSU}$, ISTO, UMR 7327, 45071 Orléans, France

${ }^{\mathrm{c} B R G M, ~ I S T O, ~ U M R ~ 7327, ~} 45060$ Orléans, France Clermont-Ferrand, France France (e-mail: alexandre.beaudoin@univ-orleans.fr; Tel: +33 2384925 73)

\section{Abstract}

${ }^{\mathrm{d}}$ Université Blaise Pascal, Laboratoire Magmas \& Volcans, CNRS, UMR 6524, 63000,

*Corresponding author: Alexandre Beaudoin, ISTO, 1A rue de la Férollerie, 45071, Orléans,

This work attempted at clarifying the structure of Ikaria using primarily intensive geological mapping combined with structural analysis and a geothermometry approach of Raman spectrometry of carbonaceous material. Foliation over the whole island defines a structural dome cored by high-grade to partially-molten rocks. Its exhumation was completed by two top-to-the-N ductile extensional shear zones, operating in the ductile and then the brittle fields, through a single extensional event coeval with progressive strain localization. 
The thermal structure of the dome with regard to position of ductile shear zones was retrieved using the Raman spectroscopy of carbonaceous material. Peak-metamorphic temperatures range from $390{ }^{\circ} \mathrm{C}$ in the upper parts of the structure down to $625^{\circ} \mathrm{C}$ in the core of the dome in the vicinity of migmatites and S-type granite. Pioneer in situ U-Th-Pb analyses on monazite performed on the leucosome parts of these rock yielded a $15.7 \pm 0.2 \mathrm{Ma}$ age. Ikaria Island thus completes the series of Miocene migmatite-cored Metamorphic Core Complex in the central part of the Aegean domain where a genuine high-temperature zone can be defined as the central Aegean HT zone. There, the extreme stretching of the continental crust is associated with dominantly top-to-the-N kinematics.

Keywords: Structural analysis; RSCM geothermometry; U-Th-Pb geochronology; Metamorphic Core Complex; Ikaria; North Cycladic Detachment System.

\section{Introduction}

In the Mediterranean realm, the retreat of oceanic slabs triggered the initiation of backarc extension (i.e large-scale extension in the upper plate of a subduction zone), leading to the collapse of previously thickened continental lithosphere (Le Pichon and Angelier, 1979; Malinverno and Ryan, 1986; Dewey, 1988; Platt and Vissers, 1989; Royden, 1993; Jolivet and Faccenna, 2000; Rosenbaum et al., 2002; Faccenna et al., 2004; Jolivet et al., 2008). This post-orogenic evolution (i.e. crustal thinning by extension-related normal faulting after an episode of crustal thickening) resulted in the formation of series of extensional domains or wide-rift systems (Lister et al., 1984; Buick, 1991; Corti et al., 2003) such as the Alboran Sea, the Tyrrhenian Sea, the Pannonian Basin and the Aegean Sea. Lateral evolution from the 
central parts of the extensional domains to the bounding non-collapsed orogenic segments implies drastic lateral gradients of finite extension and suggests highly non-cylindrical structures. In the Aegean Sea, along with the drastic decrease in topography and crustal thickness, the main orogenic structures of the Hellenic belt are increasingly reworked by extension from continental Greece to Naxos, in the center of the Aegean Sea. Extensional structures related to back-arc crustal stretching evolve from essentially brittle steep and shallow-dipping normal faults in continental Greece to shallow-dipping ductile shear zones in the center of the Aegean domain (Jolivet and Patriat, 1999; Jolivet et al., 2010). Furthermore, a straightforward correlation between the degree of non-coaxiality of the back-arc domain and the amount of stretching of the continental crust is observed at the scale of the entire Aegean domain (e.g. Augier et al., 2015). Marginal areas that connect to non-collapsed orogenic segments display symmetrically arranged detachment systems. In the western parts of the Aegean domain, both the West Cycladic Detachment System (WCDS) and the North Cycladic Detachment System (NCDS) exhume a horst-shaped domain, where orogenic features are still nicely preserved, depicting bivergent extension (e.g. Jolivet et al., 2010; Grasemann et al., 2012). Conversely, in the center of the Aegean domain, deformation remains highly asymmetric from Mykonos in the north, all the way to Sikinos in the south (e.g. Gautier et al., 1993; Kumerics et al., 2005; Denèle et al., 2011; Augier et al., 2015). There, orogenic features are particularly overprinted or even locally erased by the combined effects of intense top-tothe-N shearing and partial-melting. Migmatite-cored Metamorphic Core Complexes (MCCs), associated with Miocene intrusions, roofed by major top-to-the-N crustal-scale detachments, are described on Naxos, in the center (e.g. Lister et al., 1984; Urai et al., 1990; Buick, 1991; Gautier and Brun, 1994; Jolivet et al., 2004a; Vanderhaeghe, 2004) and Mykonos in the north of the Aegean domain (Lecomte et al., 2010; Denèle et al., 2011). Concentrating a large part of the total amount of stretching, recognition of MCCs therefore appears of prime importance. 
Similarly, asymmetry of crustal thinning at the regional-scale is another key-question for understanding back-arc extension dynamics. However, the current understanding of back-arc dynamics in the Aegean domain is hindered by the severe lack of knowledge for the bulk of its eastern part.

One of the largest Aegean islands, displaying the largest intrusion of the Aegean Sea, located between the northern Cyclades and western Turkey, Ikaria Island has been the focus of several recent studies. However, the first order structural architecture of this island remains conflicting and the existing geological maps of Ikaria present marked discrepancies. Besides, the current knowledge of the metamorphic record and particularly the thermal structure of Ikaria remain fragmentary. These problems were reconsidered after an extensive field survey, including primarily new geological mapping and structural analysis. The position and importance of the various tectonic contacts as well as the bulk thermal architecture of the island were further constrained using the geothermometry approach of Raman Spectrometry of Carbonaceous Material (RSCM). Following their recent discovery, the migmatites described in the core of the structure were dated by U-Th-Pb LA-ICPMS analyses on monazite.

\section{Geological setting}

\subsection{Geodynamic context}

The Aegean domain (Fig. 1) corresponds to the collapsed segment of the HellenidesTaurides belt, developed as the result of the convergence between Apulian and European plates, in the eastern Mediterranean, since the Late Cretaceous (e.g. Aubouin and Dercourt, 
1965; Brunn et al., 1976; Bonneau and Kienast, 1982; Bonneau, 1984; van Hinsbergen et al., 2005; Jolivet and Brun, 2010, Ring et al., 2010). During this period, a south-verging crustalscale orogenic wedge was formed by subduction and accretion of several Apulia-derived continental blocks separated by oceanic basins. Post-orogenic extension of the Hellenic thickened crust started in the Early Oligocene (Jolivet and Faccenna 2000; Jolivet et al., 2008) or the Early Miocene (Ring et al., 2010) by a combination of gravitational collapse and backarc extension during the southward retreat of the African slab (e.g. Jolivet and Faccenna, 2000; Jolivet and Brun, 2010). Intense crustal stretching of the upper plate leads to the formation of a series of MCCs (Lister et al., 1984; Avigad and Garfunkel, 1989; 1991; Gautier and Brun, 1994; Jolivet et al., 2004a). Despite the importance of the post-orogenic overprint on the orogenic architecture, the original vertical superposition of tectonic units in the nappe stack is often preserved at the scale of the whole Aegean domain (e.g. Bonneau, 1984; van Hinsbergen et al., 2005). Three main tectonometamorphic units are classically recognized (e.g. Bonneau, 1984; Ring et al., 2010) (Fig. 1):

1) The Upper Cycladic unit corresponds to a lateral equivalent of the Pelagonian nappe (e.g. Bonneau, 1984; Jolivet et al., 2004a) recognized in continental Greece. This unit generally crops out as isolated klippes or rafts in the Cyclades, essentially made of ophiolitic material such as in Andros, Tinos, Mykonos, Kea, Kythnos, Serifos and Samos (e.g. Ring et al., 1999; Jolivet et al., 2010; Grasemann et al., 2012). Rocks preserve a Cretaceous HT-LP metamorphic imprint but escaped both the Eocene $\mathrm{H} P$-LT and the Oligocene-Miocene HT-LP tectonometamorphic events (Katzir et al., 1996). Syn-tectonic detrital shallow-marine and continental sediments locally form the uppermost unit on Mykonos, Paros, Naxos and Ikaria (e.g. Angelier, 1976; Photiades, 2002a; Sánchez-Gómez et al., 2002; Kuhlemann et al., 2004; Lecomte et al., 2010). Conglomerates mostly contain pebbles derived from the Upper 
125 Cycladic nappe and reworked magmatic rocks as young as 10 Ma (e.g. Sánchez-Gómez et al.,

126

127

128

129

130

133

134

135 2002).

2) The Cycladic Blueschists unit crops out as a composite unit including locally a significant component of metabasic rocks interleaved with metapelites and marbles, all equilibrated in blueschist-facies conditions (e.g. Blake et al., 1981; Bonneau, 1984; Avigad and Garfunkel, 1991; Keiter et al., 2004). This unit experienced a complex alpine tectonometamorphic evolution, with an early burial in HP-LT conditions reaching blueschist to eclogite-facies conditions during the Eocene, followed by a greenschist overprint of variable intensity during the Oligocene and the Miocene (Altherr et al., 1979, 1982; Wijbrans et al., 1990; Parra et al., 2002; Duchêne et al., 2006; Augier et al., 2015). On Ikaria, despite the lack of reliable HP index minerals, the Messaria unit (Kumerics et al., 2005) was correlated with the Ampelos nappe recognized on Samos that experienced metamorphic conditions of the order of $15 \mathrm{kbar}$ and $500{ }^{\circ} \mathrm{C}$ (Will et al., 1998).

3) The lower units crop out in tectonic windows. The Cycladic Basement unit crops out in the central and southern Cyclades (i.e. on Naxos, Paros, Sikinos and Ios) (e.g. Andriessen et al., 1987). It is composed of Variscan granitoids mantled by micaschists that retain either metamorphic relics of amphibolite-facies assemblages or inherited radiometric ages suggesting a complex prealpine history (e.g. Henjes-Kunst and Kreuzer, 1982; Andriessen et al., 1987; Keay and Lister, 2002). It is sometimes covered by Mesozoic marbles that may represent a $\mathrm{HP}$ equivalent of the Gavrovo unit cropping out in continental Greece (Jolivet et al., 2004b). Just as the Cycladic Blueschists unit, the Cycladic Basement unit shows a complex alpine tectonometamorphic evolution, with an initial subduction-related burial in $\mathrm{H} P$-LT conditions during the Eocene whose trace has been obscured by an Oligocene-Miocene local overprint (van der Maar et al., 1981; Vandenberg and Lister, 1996; Baldwin and Lister, 1998; Augier et al., 2015). On Naxos and Paros, it experienced a partial- 
melting stage in amphibolite to granulite-facies conditions (i.e. Jansen and Schuiling, 1976; Buick and Holland, 1989; Vanderhaeghe, 2004; Duchêne et al., 2006).

Rocks of the Cycladic Blueschists and the lower units were exhumed during two distinctive stages in two contrasted geodynamic settings. The first stage occurred in the Hellenic subduction context, during the Eocene, with burial and synorogenic exhumation (by shortening-related normal faulting) of blueschist to eclogite-facies assemblages in an extrusion wedge structure (e.g. Altherr et al., 1979; Wijbrans et al., 1990; Trotet et al., 2001a; 2001b; Groppo et al., 2009; Ring et al., 2007; Jolivet and Brun, 2010). The second stage occurred in the Oligocene-Miocene with the post-orogenic exhumation in the back-arc domain of the Cycladic Blueschists and the lowers units as metamorphic domes or migmatitecored MCCs (Lister et al., 1984) below a series of detachments (e.g. Avigad and Garfunkel, 1989; Buick and Holland, 1989; Buick, 1991; Faure et al., 1991; Lee and Lister, 1992; Gautier et al., 1993; Gautier and Brun, 1994; Jolivet and Patriat, 1999; Keay et al., 2001; Vanderhaeghe, 2004; Kumerics et al., 2005; Mehl et al., 2005; 2007; Denèle et al., 2011; Augier et al., 2015). In the northern Cyclades, these detachments were recently grouped in a single large-scale top-to-the-N structure running over $130 \mathrm{~km}$ to form the NCDS (Fig. 1; Jolivet et al., 2010). A similar set of detachments with opposed, top-to-the-S or SW kinematics, was identified in the western Cyclades (Grasemann and Petrakakis, 2007; Iglseder et al., 2009, 2011; Tschegg and Grasemann, 2009; Brichau et al., 2010) and recently mechanically linked to form the WCDS (Grasemann et al., 2012). The Naxos-Paros Detachment (NDP) completes those series of detachment systems in the center of the Aegean domain (Buick and Holland, 1989; Buick, 1991; Gautier and Brun, 1994; Kruckenberg et al., 2011). Another major shear zone over which top-to-the-N kinematics rework top-to-the-S shear sense occurs in the southern Cyclades on the islands of Sikinos and Ios (e.g. Vandenberg and Lister, 1996; Forster and Lister, 2009; Huet et al., 2009; Thomson et al., 
2009; Augier et al., 2015). Extension on this shear zone starts to exhume rocks near the Early Miocene (Thomson et al., 2009). Here, top-to-the-S kinematics was first considered as extensional (Vandenberg and Lister, 1996; Forster and Lister, 2009; Thomson et al., 2009) and later correlated with the WCDS (Ring et al., 2011). Another study reinterpreted this shear zone as a top-to-the-S thrust reworked by top-to-the-N extension (the South Cycladic Thrust, SCT) (Huet et al., 2009). The same interpretation is made on Sikinos where the SCT crops out (Augier et al., 2015). Late exhumation stages along extensional systems were accompanied by the emplacement of syn-tectonic Miocene I and S-type granites (i.e. Tinos, Mykonos, Naxos, Serifos and Ikaria; Fig. 1) (Faure et al., 1991; Lee and Lister, 1992; Altherr and Siebel, 2002; Grasemann and Petrakakis, 2007; Ring, 2007; Iglseder et al., 2009; Bolhar et al., 2010; Laurent et al., 2015). The activity of detachments is also constrained by syn-tectonic deposition of sediments over the Upper Cycladic unit (e.g. Sanchez-Gomez et al., 2002; Kuhlemann et al., 2004; Lecomte et al., 2010; Menant et al., 2013).

Although part of these features of the Cycladic geology are found further east within the Menderes massif (Fig. 1), type, distribution and timing of metamorphism appear less clear. The Cycladic Blueschists unit and the Lycian Nappe that experienced HP-LT metamorphic conditions rest on top of the structure to the north and to the south of the massif (Oberhänsli et al., 1998; Rimmelé et al., 2003a; 2003b; Pourteau et al., 2010). HP-LT metamorphic conditions are dated from Late Cretaceous to Eocene (Oberhänsli et al., 1998; Pourteau et al., 2013). Crustal stretching responsible for the final exhumation of the metamorphic part of the Menderes massif under shallow-dipping shear zones (e.g. Rimmelé et al., 2003b; Bozkurt, 2007; van Hinsbergen; 2010; Bozkurt et al., 2011) is very similar to the Cyclades one. Detachments juxtapose Neogene syn-tectonic sediments on metamorphic rocks that are strongly retrograded in the greenschist facies during the Miocene (Hetzel et al., 
1995a; Lips et al., 2001). Here again, crustal thinning is accompanied by the emplacement of syn-tectonic granites (Ring and Collins, 2005; Glodny and Hetzel, 2007).

2.2. Geology of Ikaria

Ikaria is a $40 \mathrm{~km}$-long island located in the eastern Aegean Sea between Mykonos and Samos. A recent map coverage was performed by the Greek Institute of Geology and Mineral Exploration (G-IGME) (Photiades, 2002b), complemented by independent geological maps presenting highly conflicting interpretations (Papanikolaou, 1978; Kumerics et al., 2005; Ring, 2007; Bolhar et al., 2010; Kokkalas and Aydin, 2013).

At first glance, the geology of Ikaria consists in an equal distribution of a metamorphic domain to the east and a large-scale magmatic complex to the west, bounded by sedimentary rocks (Fig. 2). The metamorphic part consists in a 1500 m-thick tectonometamorphic succession made of metasediments including metapelites, metaquartzites, marbles and minor metabasites occurrences passing upward to finely alternating metapelites and marbles (Photiades, 2002a; 2002b; Kumerics et al., 2005). The metamorphic grade decreases upward from widespread amphibolite-facies associations (i.e. staurolite-garnet-biotite in metapelites and hornblende-plagioclase in metabasites) to greenschists-facies associations in the uppermost parts of the succession (e.g. Altherr et al., 1982; Kumerics et al., 2005; Martin et al., 2011). Peak-metamorphic conditions, as retrieved from pseudo-section approaches, yielded 6-8 kbar for $600-650{ }^{\circ} \mathrm{C}$ conditions for the basal parts of the tectonometamorphic succession (Kumerics et al., 2005; Martin et al., 2011), fringing partial-melting conditions assuming water saturation conditions (Weinberg and Hasalova, 2015). While similar quantitative P-T estimates are currently lacking for the upper parts of the succession, a 
224

localized change in the metamorphic grade has however been proposed within the upper parts (Papanikolaou, 1978; Altherr et al., 1982; Kumerics et al., 2005). Besides, it is noteworthy that traces of an initial $\mathrm{H} P$ imprint is currently lacking on Ikaria, at variance with neighboring islands (Altherr et al., 1982; Photiades, 2002a; Kumerics et al., 2005; Ring, 2007).

Three main magmatic intrusions were recognized on Ikaria (Papanikolaou, 1978; Photiades, 2002b; Ring, 2007); two small-scale, less than $10 \mathrm{~km}^{2}$ S-type two-mica leucogranite intrusions (i.e. the Xylosyrtis and the Karkinagrion intrusions) and a large-scale I-type intrusion (i.e. the Raches intrusion). Along with a related pervasive pegmatite dyke array (Photiades, 2002b; Hezel et al., 2011), the Xylosyrtis pluton displays a clear intrusive character within the metamorphic series. Conversely, the nature of the Raches granite contact remains highly controversial and was mapped so far as intrusive (Papanikolaou, 1978; Laurent et al., 2015), as a detachment (Kumerics et al., 2005) or as a thrust (Photiades, 2002a; 2002b; Kokkalas and Aydin, 2013). Emplacement of the main intrusions occurred in a narrow 15-13 Ma age-range (Bolhar et al., 2010).

Metamorphic and intrusive rocks experienced an intense top-to-the- $\mathrm{N}$ shearing in both ductile and then brittle regimes (Kumerics et al., 2005; Ring, 2007). The Raches intrusion in the west thus shows a top-to-the-N strain gradient toward the upper structural levels, from proto-mylonites to ultra-mylonites, and finally cataclasites (Laurent et al., 2015). Prior to this study, two main tectonic contacts, along which deformation is concentrated, were distinguished: the Messaria and Fanari detachments (Kumerics et al., 2005). According to Kumerics et al. (2005), the Messaria detachment corresponds to a mylonite zone later partly overprinted by cataclastic deformation. At variance, the Fanari detachment is currently regarded as a purely brittle contact roofing the metamorphic rocks and bounding the sediments of the upper unit (Kumerics et al., 2005; Ring, 2007). This unit, regionally known as the Fanari unit, consists in sandstones, siltites and conglomerates containing clasts of red 
cherts and ophiolitic rocks of Early Cretaceous age and large-scale olistoliths of Triassic 250 recrystallized limestones (Papanikolaou, 1978) reminding typically rocks of Pelagonian 251 affinity (Pe-Piper and Photiades, 2006). Ages of those sediments spread from Oligocene to 252 Pliocene (Photiades, 2002a; 2002b). In the center of the island, the recrystallized limestone of 253 Kefala, inferred as Triassic, is sometimes described as a klippe of the upper unit of Ikaria 254 (Papanikolaou, 1978; Photiades, 2002a; 2002b; Pe-piper and Photiades, 2006). The main 255 argument for the presence of the Pelagonian unit relies on the description of a diorite intrusive body that yielded Cretaceous K/Ar ages on hornblende (Altherr et al., 1994). the onset of extensional motions along main shear zones are currently lacking on Ikaria. First record of cooling, below $550{ }^{\circ} \mathrm{C}$ (Villa, 1998), is scattered between 25 and $17 \mathrm{Ma}$ (K/Ar on 260 hornblende; Altherr et al., 1982). Late exhumation stages are, in turn, well constrained after 15 Ma by varied thermochronological tools (Altherr et al., 1982; Kumerics et al., 2005). The $\mathrm{K} / \mathrm{Ar}$ and Ar/Ar ages on both fabric-forming white mica and biotite yield numerous 12 to 9 Ma ages. In metamorphic rocks, these ages are interpreted as both cooling or deformation ages during exhumation while they are considered as cooling ages for granites (Altherr et al., 1982; Kumerics et al., 2005). Fission-track (FT) analyses yielded $10.3 \pm 0.3$ to $7.1 \pm 0.3 \mathrm{Ma}$ ages for zircon and $8.4 \pm 0.8$ to $5.9 \pm 0.8$ Ma ages for apatite (Kumerics et al., 2005). Final cooling stages were constrained by $\mathrm{U}-\mathrm{Th} / \mathrm{He}$ analyses on apatite that yielded symmetrically arranged $6 \mathrm{Ma}$ ages for both flanks and a $3 \mathrm{Ma}$ age for the core of the structure (Kumerics et al., 2005). Cooling rates therefore exceeded $100{ }^{\circ} \mathrm{C} / \mathrm{Ma}$ from the ductile to brittle transition (i.e. 300-400 ${ }^{\circ} \mathrm{C}$, Stöckhert et al., 1999; Imber et al., 2001) and temperatures as low as $70{ }^{\circ} \mathrm{C}$ between 10 to $6 \mathrm{Ma}$. 
An extensive field survey was carried out on Ikaria including new field mapping in order to complement the existing G-IGME geological map (Photiades, 2002b). The result is presented in Fig. 2; readers are referred to existing maps showing very conflicting interpretations to appreciate the modifications (Papanikolaou, 1978; Photiades, 2002b; Kumerics et al., 2005; Ring, 2007; Bolhar et al., 2010; Kokkalas and Aydin, 2013). For clarity, the lithostratigraphic subdivisions of Photiades (2002b) were kept as much as possible. Three main lithologies, including marbles, micaschists (including calcschists and minor metaquartzites and metabasites occurrences) and granitic rocks derived from three main intrusive bodies were mapped (Fig. 2). Definition of the main tectonic units changed as the result of the modification and the reinterpretation of their boundaries, particularly the tectonic and intrusive contacts. Three main tectonic units, from bottom to top: the Ikaria, AgiosKirykos and Fanari units, limited by two major shear zones, are now distinguished. The main tectonic features having a map-scale expression were also reported in detail. These structures consist primarily in the Agios-Kirykos and the Fanari ductile shear zones developed as rampflat extensional structures either at shallow-angle to the compositional layering as décollement zones or cutting down-section. The Fanari shear zone even presents evidence for subsequent displacements in the brittle field superimposed on ductile features. On the map, the Fanari detachment clearly cuts across the whole Agios-Kirykos unit and the Agios-Kirykos shear 294 zone. Other shear zones or brittle contacts put forward on previous maps were abandoned. 295 The basal contact below Kefala marble (e.g. Papanikolaou, 1978; Altherr et al., 1994; 296 Photiades, 2002a; 2002b; Pe-piper and Photiades, 2006) is considered less important than in 297 previous studies since no metamorphic gap is backed up by published data. Moreover, 298 detailed mapping of this zone indicate that the diorite is intrusive in Ikaria unit. However, a 
panorama on the Kefala marble seen suggests the presence of a tectonic contact at its base

300 (Papanikolaou, 1978). Although probably minor, this contact might be a late brittle expression

301 of the system of detachments. Similarly, the nature of the eastern contact of the Raches

302 granite considered either as the lateral equivalent of the Messaria detachment (Kumerics et al.,

303 2005; Ring, 2007) or a major thrust contact (Photiades, 2002a; 2002b; Kokkalas and Aydin,

304 2013) was re-evaluated. Field work in the vicinity of the contact of the Raches granite

305 unambiguously shows, despite ductile deformation, the clear intrusive character of the granite

306 within Ikaria unit (Fig. 3a) as suggested in earlier studies (e.g. Papanikolaou, 1978; Laurent et

307 al., 2015). Along with the Fanari detachment, the Fanari sedimentary unit of Kumerics et al.

308 (2005) was extended further southwest (Fig. 3b). This sedimentary unit was correlated to

309 sediments recognized on the northern part of Ikaria at Gialiskari (Fig. 3c) as initially proposed

310 by Photiades (2002a; 2002b) and recently reinforced by Laurent et al. (2015). There, the

311 Fanari sedimentary unit lies on top of a thick cataclastic body (Figs. 3c and 3d) superimposed

312 over a 300-500 m-thick ductile strain gradient developed within both the Raches and

313 Karkinagrion granites (Laurent et al., 2015). Besides, the initial geological outline of the

314 Karkinagrion granite (Ring, 2007) was significantly modified and extended toward the north

315 (Fig. 2). Detailed field work within and around this granite massif allows the recognition of a

316 large-scale migmatite complex closely associated with this S-type granite (see recent

317 description in Laurent et al. (2015)) (Fig. 3e).

320 4. Structural analysis of the ductile deformation in metamorphic rocks

\subsection{Main planar fabrics}


All metamorphic rocks and most of magmatic lithologies from Ikaria are pervasively

325 foliated. In most cases, compositional layering in the metasediments has been transposed into 326 a main, generally shallow-angle foliation.

327221 foliation planes were measured in all lithologies of the two metamorphic units.

328 Besides, bedding was measured in Fanari unit. Measurements, statistical analysis and foliation

329 trajectories are reported on Figs. 4a, b and c, respectively. The dip of foliation planes displays

330 a large range of variation between $10^{\circ}$ and $50^{\circ}$ for a mean value at $20-25^{\circ}$ (Fig. $4 \mathrm{~b}$ ).

331 Smoothing out these small-scale dip variations, the main foliation planes commonly dip away

332 from the long axis of the island. The strike of foliation therefore shows a fairly concentric 333 pattern depicting a NE-SW elongated structural dome (Fig. 4c), which ends in the northeast.

334 The dome axis, issued from the inversion of field measurements, trends $\mathrm{N} 037^{\circ} \mathrm{E}$, which 335 corresponds to the main orientation of regional foliation (Figs. $4 \mathrm{~b}$ and 4c). Additionally, this 336 dome presents a marked asymmetry with a steeper, $30-40^{\circ}$ dipping southeastern flank (Fig. 337 4b). The deeper parts of the dome crop out in the central part of the southern coast of the 338 island, close to the contact with the Raches granite. Toward the southwest, the axis extends 339 seaward and turns to a more E-W orientation to finally show up again across the main 340 occurrence of migmatites (Fig. 4c). Strike and dip of the main foliation are generally 341 discontinuous across intrusive contact of the Raches intrusion, particularly to the south. 342 Conversely, foliation trajectories are more continuous to the north where both the granite and 343 the wall-rocks locally present an ultramylonitic fabric (Fig. 4c).

\subsection{Stretching lineation}


Stretching lineation is carried by the foliation plane in most metamorphic rocks, while

349 it may sometimes occur as the unique strain marker in the intrusive rocks. It is marked by 350 various indicators, depending on lithology, metamorphic grade and strain intensity. In calcite 351 and dolomite marbles, it is defined by very fine-grained mica slates and the elongation of 352 graphite-rich inclusions. In metapelites, it is generally defined by elongated quartz rods and 353 phyllosilicate aggregates. It is also sometimes marked by the elongation and the truncation of 354 epidote or tourmaline in granitic rocks. Evidence for stretching is also recorded by the 355 preferred elongation and the brittle truncation of clasts in conglomeratic layers at the base of Fanari unit, just above the Fanari detachment. 202 stretching lineations have been measured in the field in all metamorphic rocks. Data are all reported in Fig. 5 together with some first-order statistics. At first glance, the trend of lineation shows very little dispersion. It is centered on an average value of $\mathrm{N} 008^{\circ} \mathrm{E}$ ranging from $\mathrm{N} 160^{\circ} \mathrm{E}$ and $\mathrm{N} 020^{\circ} \mathrm{E}$ (Fig. 5b). Wrapped around the dome, the lineation plunges to the north in the northwestern flank of the island and to the south in the southeastern flank. At large-scale, the trend of stretching lineation describes slightly curved patterns from N-S to more NNE-SSW directions. The spatial rotation of the stretching lineation can be correlated with the relative structural position; NNE-SSW orientations are observed in the uppermost parts of the metamorphic succession and particularly in the vicinity of the Fanari shear zone, in the northeast of Ikaria or at Gialiskari (Fig. 5a).

4.3. Asymmetry of ductile deformation

The whole volume of the metamorphic succession and a great part of the magmatic 
373 (Fig. 5a). Kinematics indicators of top-to-the-N deformation are very common and often

374 unambiguous, particularly toward the top of Ikaria unit and in the bulk of Agios-Kirykos unit.

375 Differing in terms of style, asymmetry and physical conditions of deformation, descriptions in

376 Ikaria and Agios-Kirykos units are presented separately.

4.3.1. Top-to-the-N shearing gradient in Ikaria unit

Shear bands accompanied by asymmetric boudinage are the most common kinematic indicators in Ikaria unit (Fig. 6). Top-to-the-N shear bands are particularly abundant in metapelite layers interleaved with more competent rocks such as marbles, metaquartzites or metabasites. Due to asymmetric dome-shaped architecture of the island, shear bands display, in their present position, gentle to moderate north-westward dips and normal-sense displacements on the northwestern flank of the island while they often present flat or even "reverse" geometry on the southeastern flank. Boudinage occurs at various scales in alternating lithologies such as metapelites interleaved with marbles, metaquartzites or metabasites. Boudins frequently show asymmetric shapes consistent with a northward asymmetry. However, antithetic bookshelf structures compatible with a top-to-the-N sense of shear can be developed within marble at different scales as observed by Ring (2007). primarily controlled by the relative structural position. Evolution of its asymmetry can be

394 studied along a composite cross-section from the deepest parts to the top of this unit from 395 Plagia to Evdilos. The deepest parts crop out on the southeastern coast between Chrisostomos 396 and Plagia. There, the most typical structural feature is an intense folding of the primary 397 compositional layering (Fig. 6a). Folds display a wide range of morphologies but all share 
common subhorizontal axial planes consistent with vertical flattening. A N-S stretching

399 lineation is only developed in metapelitic or sometimes quartzitic layers while other

400 lithologies display more randomly oriented intersection lineations. Sense of shear is often

401 ambiguous with the presence of both top-to-the-N and top-to-the-S shear criteria suggesting a

402 strong flattening component. Upward, the development of meter-scale decimeter-thick shear

403 bands marks the appearance of a clear asymmetry. Shear bands delimit asymmetric boudins

404 that preserve more ductile deformation as tight recumbent to isoclinal folds, or only as 405 detached fold hinges (Fig. 6b). However, at variance with deeper levels of the unit, fold axes 406 trend parallel to the stretching lineation arguing for a significant component of shearing in the 407 direction of stretching (Fig. 6c). Upward, along with the multiplication of shear bands, the 408 decreasing size of shear domains and boudins, metapelitic rocks become more homogeneous.

409 Lenses of metabasites, dolomitic marbles and remains of metaquartzites occur as sigma or more rarely delta-type porphyroclasts systems consistent with an overall top-to-the-N sense of 411 shear (Fig. 6d). Intense shear strain has turned the rocks into fine-grained mylonites (Fig. 6e). 412 The resulting cross-section shows a first-order strain gradient, where asymmetric stretching is 413 more and more systematic toward the highest structural levels of the unit (Fig. 6f).

414 Metamorphic conditions that prevailed during deformation also depend on structural 415 position. Amphibolite-facies assemblages and gneisses are generally well preserved in the 416 deepest parts of Ikaria unit. There, first retrogression stages are clearly synkinematic, as 417 exemplified by the crystallization of biotite around stable garnets forming sigma-type 418 porphyroclasts system (Fig. 7a). Upward, developed during garnet breakdown, asymmetric 419 strain shadows around garnet contain chlorite and white-micas. Biotite, still metastable in the 420 bulk of the rock is retrograded to chlorite in shear bands. Associated with the crystallization 421 of large amounts of synkinematic chlorite and albite, top-to-the- $\mathrm{N}$ shearing in the highest 422 levels was clearly recorded within greenschist-facies metamorphic conditions (Fig. 7b). 

from Therma to Agios Kiriaki (see location on Fig. 2). It consists in the alternation of marble and dark metapelites layers reaching 150-200 m of structural thickness. On most outcrops, top-to-the-NNE ductile shearing is clear. Greenschist-facies shear bands are abundant and display a clear upward evolution to more localized or even cataclastic flow (compare Fig. 8a and Fig. 8b). The core of Fanari shear zone, developed at the expense of the uppermost parts of Ikaria unit, is well exposed in the western part of Agios Kiriaki harbor (Fig. 8c). While the contact itself is hidden by the airport runaway, Fanari unit crops out directly to the northeast, $100 \mathrm{~m}$ apart (Fig. 8c). There, rocks present a northeast-dipping mylonitic fabric and carry a $\mathrm{N} 035^{\circ} \mathrm{E}$ stretching lineation marked by numerous quartz rods and boudins of all sizes from a few centimeters to several meters. Marble layers are stretched and boudinaged within the 438 metapelitic matrix. The internal deformation of marbles displays successive stages of 439 symmetric boudinage, evolving from ductile to brittle (Fig. 8d). Metapelite levels show a 440 clear non-coaxial component of shearing consistent with an overall top-to-the-NNE 441 kinematics (Fig. 8e). These layers, generally thinned to $1 \mathrm{~m}$ or even less, display a single and 442 penetrative set of shear bands locally obliterating the main foliation. Spacing between shear 443 bands, controlled by the presence of quartz lenses is locally as small as 1-3 cm (Fig. 8e). 444 Chlorite is abundant within these rocks and adopts a clear synkinematic character in the 445 vicinity of shear bands. The brittle expression of the Fanari shear zone is not exposed there 446 but occurs spectacularly near Fanari, $1 \mathrm{~km}$ further south along the coast (Fig. 9). The Fanari 447 detachment is described in the next section. 
5. Brittle deformation analysis

Ikaria presents either large to meso-scale brittle structures or locally pervasive networks of small-scale brittle faults systems developed from the ductile-brittle transition to the brittle field. Brittle structures of all scales are first described. Results of the paleostress analysis are then presented. It must be noted here that some NNE-SSW lineaments, visible on satellite images, do not have any particular expression in the field.

5.1. Description of brittle structures

The Fanari detachment is the only large-scale structure that was active under both

462 ductile and subsequent brittle conditions. Displacement in the brittle regime over the Fanari 463 detachment is attested by the development of cataclasites particularly well exposed along the 464 southeastern coast of the island as a series of several hundreds of meters of continuous 465 outcrops (Fig. 9). There, the detachment plane appears stripped of its sedimentary cover over 466 a large surface revealing large-scale corrugations and crescent-shaped structures that remind 467 the Cape Evros outcrop on Mykonos (Lecomte et al., 2010; Menant et al., 2013) or the Platy 468 Gialos outcrop on Serifos (Grasemann and Petrakakis, 2007). Breccias, locally reaching more 469 than $2 \mathrm{~m}$, are mainly developed at the expense of Agios-Kirykos unit but also from the very 470 first decimeters of Fanari unit. Cataclastic rocks often show typical clasts size ranging from 1 471 to $20 \mathrm{~cm}$ embedded in reddish-brownish cement supposed to be composed of Fe-rich oxy472 hydroxides and carbonates. The detachment plane displays a NE-SW strike and a $60^{\circ}$ 
473 southeast-dip. It carries shallow-dipping, southwest-plunging, large-scale corrugations

474 consistent with the opening of perpendicular cracks. Variable types of kinematics indicators

475 of top-to-the-NNE brittle deformation in the detachment footwall unambiguously ascribe a

476 left-lateral reverse sense of displacement. A secondary discrete striae indicates locally a

477 reverse sense of displacement. At the scale of the map, kinematics of brittle motion over

478 Fanari detachment indicates northeast-directed displacement consistent with the kinematics of

479 the last increments of ductile deformation (compare kinematics given on Fig. 9 with the last

480 ductile stretching lineation on Fig. 5). In its current position, the detachment plane is offset by

481 a set of NW-SE vertical faults carrying oblique striations.

Cataclastic rocks also occur on the northern part of Ikaria at Gialiskari (Figs. 3c and

3d). They overprint the uppermost parts of a 500 m-thick strain gradient developed

484 exclusively at the expense of the underlying Raches granite (Laurent et al., 2015). Here, they bound again a tectonic unit considered as the lateral equivalent of Fanari unit exposed further

east. Sediments, consisting on alternating grey sandstones, conglomerates and brownish

limestones are heavily affected by extensional features. WNW-ESE normal faults are organized in conjugate sets accompanied by a dense array of subvertical WNW-ESE veins that both overprint a gently south-dipping bedding.

Beside this major brittle structure, small-scale brittle features mostly correspond to late

491 W-E to NW-SE conjugate faults systems developed in all lithologies (Figs. 10 and 11).

492 Displacement on faults ranges typically from a few centimeters to a few meters and can 493 generally be constrained in the field using marker-levels. In the entire studied area, the fault 494 population is dominated by dihedral orientations arguing for the formation of newly formed 495 conjugate sets of faults rather than reactivated shear planes. Normal faults are often accompanied by subvertical joints and tension gashes filled with quartz, chlorite, iron oxy-

497 hydroxides in the metamorphic rocks, quartz, chlorite or even epidote and tourmaline in 
granites and mostly calcite in the sediments. The close association between faults and joints

499 often displays contradictory intersection relationships and thus argues for a contemporaneous 500 development.

5.2. Inversion of fault-slip data

504

Paleostress orientation patterns were evaluated by the Win-Tensor computer-aided inversion software (Delvaux and Sperner, 2003). The reduced paleostress tensor consists in the identification of orientation of the three principal stress axes and the axial ratio of stress ellipsoid. Determination of the paleostress axes was completed by the analysis of accompanying brittle structures such as joints, tension gashes or stretched pebbles. Brittle structure analysis was conducted over 9 main sites scattered over the island (see Fig. 5 for location). Results are presented in the next two sections.

5.2.1. Using microstructures to unfold the Fanari detachment

Although the Fanari detachment consistently exhibits top-to-the-NE kinematics, it currently crops out with the geometry of southeast-dipping left-lateral reverse fault zone, a

518 quite rare configuration in the Aegean domain (Fig. 9). A detailed study of geometrical 519 relationships between detachment, sediments of Fanari unit and attitude of small-scale brittle structures affecting either the sediments or the detachment plane, allows proposing a restoration scenario of the initial geometry of the Fanari detachment (Fig. 10a). Two reference outcrops (6 and 7) were selected $2 \mathrm{~km}$ apart within sediments of Fanari unit along the 
detachment (see position on Fig. 5) with contrasting spatial relationships between structures. Outcrop of station 7 (Fig. 10b), which presents almost vertical bedding, displays a conjugate set of subvertical faults affecting alternating sandstones and conglomeratic layers. $\mathrm{N} 030^{\circ} \mathrm{E}$ to $\mathrm{N} 160^{\circ} \mathrm{E}$ faults present consistent sinistral kinematics while $\mathrm{N} 070^{\circ} \mathrm{E}$ to $\mathrm{N} 130^{\circ} \mathrm{E}$ faults present dextral kinematics. Part of these faults even cuts across the Fanari detachment causing 1-5 m offsets of the plane. Outcrop of station 6 also presents two sets of faults that affect a $40^{\circ}$ dipping bedding further southeastward. The dominant set of faults displays subvertical fault planes carrying both normal and reverse kinematics. This set is accompanied by a subordinate set of flat to gently-dipping fault planes that also present both normal and reverse kinematics (Fig. 10b). In their present geometry, this heterogeneous fault set requires the superimposition of two distinct stress regimes. Back-tilting of those systems of faults about a horizontal axis, in order to obtain a horizontal bedding, permits to get a coherent stress regimes for both sites 6 and 7. Maximum principal stress axis becomes vertical and the two others become horizontal, compatibly with a NE-SW extension for both sites. It strongly suggests that faults form before an unequal tilting of the different outcrops. This assumption is confirmed further to the southwest where both the detachment plane and the bedding of sediments are subhorizontal (i.e. less than $20^{\circ}$ toward the southwest) while tension-gashes are now subvertical and all faults appear as a single conjugate normal fault set preserved in its initial attitude. Importantly, back-tilting of the whole system, including the Fanari detachment, results in a system where the detachment plane operates at shallow angle, $10-15^{\circ}$ to the northwest, with normal-dextral-sense kinematics and cuts the sediments down-section as observed in the neighboring island of Mykonos (e.g. Lecomte et al., 2010; Menant et al., 2013). In this restored position (Fig. 10a), sediments are pervasively affected by normal faulting consistent with a unique and common NNE-SSW to NE-SW extension (Fig. 10b). This paleostress solution is consistent with the paleostress field deduced from other stations 
548 throughout the island and previous studies (e.g. Kumerics et al., 2005). This point is discussed

549 below. The causes of the Fanari detachment tilting and the more general arching of the ductile

550 to brittle fabrics at the scale of the whole island are addressed in the discussion section.

5.2.2. Large-scale consistency of the paleostress inversions

554 carbonaceous material $(\mathrm{CM})$, which is a reliable indicator of metamorphic temperature (e.g.

Despite the local coexistence of both $\mathrm{N} 80-110^{\circ} \mathrm{E}$ and $\mathrm{N} 130-160^{\circ} \mathrm{E}$ trending normal faults, results present rather small internal dispersion (Fig. 11). At most stations, stress tensor analysis shows a consistent subvertical orientation for the maximum principal stress axis $\left(\sigma_{1}\right)$. In other stations (e.g. sites 6 and 7 on Fig. 10b), $\sigma_{1}$ was restored using horizontal-axis backtilting rotation. The minimum principal stress axis $\left(\sigma_{3}\right)$ is horizontal or very gently dipping with a consistent NNE-SSW to more NE-SW direction of extension. In turn, the overall consistency of the direction of $\sigma_{3}$ prevents from significant vertical-axis large-scale block rotations. Planes of joint and tension gashes correspond to the calculated $\sigma_{1}-\sigma_{2}$ plane, and their poles therefore appear scattered around the $\sigma_{3}$ axis. Brittle structures recorded during the last exhumation stages present a marked consistency of a NE-SW stretching direction occurring in an extensional regime.

\section{Thermal structure}

Pasteris and Wopenka, 1991; Beyssac et al., 2002; Lahfid et al., 2010). Because of the 
573 irreversible character of graphitization, $\mathrm{CM}$ structure is not sensitive to the retrograde

574 reactions and permits to determine peak temperature conditions $\left(\mathrm{T}_{\max }\right)$ reached during 575 metamorphism, using an area ratio (R2 ratio) of different peak of Raman spectra (Beyssac et 576 al., 2002). $\mathrm{T}_{\max }$ can be determined in the $300-640{ }^{\circ} \mathrm{C}$ range with an accuracy of $\pm 50{ }^{\circ} \mathrm{C}$ 577 related with the precision and the dispersion of petrological data used for the method 578 calibration (Beyssac et al., 2002). Relative uncertainties on $\mathrm{T}_{\max }$ are however much smaller, 579 around $10-15{ }^{\circ} \mathrm{C}$ and relative variations of that order of magnitude can be detected (e.g. 580 Gabalda et al., 2009; Vitale Brovarone et al., 2013; Augier et al., 2015). Sampling was 581 performed in order to quantitatively describe the large-scale thermal structure of Ikaria to 582 complement the few existing, punctual P-T estimates (Kumerics et al., 2005; Martin et al., 583 2011). Sampling was therefore regularly distributed within the tectonometamorphic 584 succession of Ikaria and a more systematic sampling was carried out in the vicinity of possible 585 second-order thermal effects such as intrusions and tectonic contacts. 35 samples consisting of 586 CM-bearing metasediments were collected (see Fig. 12 for location). In order to bring out and 587 possibly smooth out the inner structural heterogeneity of CM within samples, 13 to 20 spectra 588 were recorded for each sample. Detailed results, including R2 ratio, number of spectra, $\mathrm{T}_{\max }$ 589 and standard deviation are presented on Table 1. In addition, RSCM temperatures are all 590 reported on Fig. 12.

RSCM results embrace a wide range of temperature from 391 to $625^{\circ} \mathrm{C}$ (Table 1). At

592 first glance, $\mathrm{T}_{\max }$ presents a correlation with the relative structural position. $625{ }^{\circ} \mathrm{C}$ was 593 indeed recorded for the deepest parts of the structural dome with gneisses while $390{ }^{\circ} \mathrm{C}$ was 594 retrieved for the uppermost parts of the metamorphic succession where low-crystallinity 595 micaschists crop out. Ikaria therefore appears as a metamorphic dome in which temperature 596 increases down-section (Figs. 12a and 12b). Samples from Ikaria unit show rather high $\mathrm{T}_{\max }$, 597 from 625 to $500{ }^{\circ} \mathrm{C}$, presenting an important scatter. The $550{ }^{\circ} \mathrm{C}$ temperatures for the volume 
of Ikaria unit are moreover consistent with the amphibolite-facies metamorphic associations.

599 Samples from Agios-Kirykos unit display lower temperature ranging between 450 and $390{ }^{\circ} \mathrm{C}$

600 (Table 1). Two main sets of temperatures can then be identified separated by a $50{ }^{\circ} \mathrm{C}$

601 temperature gap (Figs. 12a and 12b). This gap of temperature corresponds to the position of

602 the Agios-Kirykos shear zone, independently recognized on the basis of structural criteria.

603 This particular feature was studied in the east of Ikaria, and particularly along a foliation-

604 orthogonal cross-section upstream of Therma valley (Fig. 12b). There, $T_{\max }$ shows a regular

605

606

607

608

609

610

611

612

613

614

615

616

617

618

619

620

621

622

\section{8} temperature decrease from 600 to $400{ }^{\circ} \mathrm{C}$ accompanied by a $50{ }^{\circ} \mathrm{C}$ normal-sense metamorphic gap. Among the causes of temperature variation in Ikaria unit, local heating by intrusive rocks has been tested in the vicinity of the Raches granite (Fig. 12c). Samples were picked at decreasing distance from the intrusive contact for almost the same relative structural position.

Results show regularly decreasing temperatures from $580{ }^{\circ} \mathrm{C}$ to $520^{\circ} \mathrm{C}$, in accordance with the intrusive character of the Raches granite (Fig. 3a). Accordingly, smaller intrusive bodies as the Kefala diorite or small-scale pegmatite dykes that are only partly mapped (Fig. 2) may be responsible of erratic, isolated high $\mathrm{T}_{\max }$ results.

(1)

\section{Age constrains on the partial melting event}

6

\subsection{Analytical methods}

Analyses were performed in thin section by laser ablation inductively coupled plasma spectrometry (LA-ICPMS) at the Laboratoire Magmas et Volcans (LMV), Clermont-Ferrand (France). The ablation is performed using a Resonetics Resolution M-50E system equipped with an ultra-short pulse $(<4 \mathrm{~ns})$ ATL excimer $193 \mathrm{~nm}$ wavelength laser. This laser system is 
623

624

625

626

627

coupled with Agilent 7500 cs ICP-MS equipped with a pumping system to enhance the sensitivity. Spot diameter of $9 \mu \mathrm{m}$ was used with a $1 \mathrm{~Hz}$ repetition rates. Ablated material is transported using a helium flux, and then mixed with nitrogen and argon before being injected into the plasma source. Analytical procedures for monazite dating are reported in details in Didier et al. (2013), Didier et al. (2014) and Paquette and Tiepolo (2007). Following isotopes ${ }^{204}(\mathrm{~Pb}+\mathrm{Hg}),{ }^{206} \mathrm{~Pb},{ }^{207} \mathrm{~Pb},{ }^{208} \mathrm{~Pb},{ }^{232} \mathrm{Th}$ and ${ }^{238} \mathrm{U}$ were acquired. Data disturbed by inclusions, fractures or age mixing (between different areas of a single grain) were not taken into account for calculation. The occurrence of initial $\mathrm{Pb}$ in the sample can be monitored by the evolution of the ${ }^{204}(\mathrm{~Pb}+\mathrm{Hg})$ signal intensity, but no $\mathrm{Pb}$ correction was applied. Elemental fractionation and mass bias were corrected making repeated analyses on Trebilcock monazite (272 \pm 2 Ma, Tomascak et al., 1996). Analyses on the Moacyr monazite (Cruz et al. 1996; SeydouxGuillaume et al. 2002; Gasquet et al. 2010; Fletcher et al. 2010) at the beginning and at the end of each session, treated as unknowns, verify the reproducibility, especially for the ${ }^{208} \mathrm{~Pb} /{ }^{232} \mathrm{Th}$ ages, and the accuracy of the corrections. Data reduction was carried out with GLITTER ${ }^{\circ}$ software package (van Achterbergh et al. 2001; Jackson et al. 2004). Calculated ratios were exported and age diagrams were generated using Isoplot software package by Ludwig (2001).

In this study, ${ }^{208} \mathrm{~Pb} /{ }^{232} \mathrm{Th}$ ages are preferably used because: 1$) \mathrm{U}$ decay series could be in disequilibrium in young monazites (Schärer, 1984), resulting in overestimated ${ }^{206} \mathrm{~Pb} /{ }^{238} \mathrm{U}$ ages; 2) ${ }^{232} \mathrm{Th}$ is so abundant that ${ }^{208} \mathrm{~Pb}$ originating from initial $\mathrm{Pb}$ is negligible compared to radiogenic ${ }^{208} \mathrm{~Pb}$ (Janots et al. 2012; Didier et al. 2013). However, in this study, ${ }^{206} \mathrm{~Pb} /{ }^{238} \mathrm{U}$ ages are fully consistent with the ${ }^{208} \mathrm{~Pb} /{ }^{232} \mathrm{Th}$ ages suggesting the absence of disequilibrium in the $\mathrm{U}$ decay series. Slight common $\mathrm{Pb}$ contamination is suggested by the Tera Wasserburg diagram, enhanced by the large uncertainty of the ${ }^{207} \mathrm{~Pb} /{ }^{235} \mathrm{U}$ ages due to very low ${ }^{207} \mathrm{~Pb}$ content in young monazite ages. 

one migmatite sample (IK01A; see Fig. 2 for localization; Qz, Pl, Afs, Bt, Sil and Zrn).

Monazites often appear as inclusions in biotite or set at grain boundaries and occur as large pristine crystals (Fig. 13a; between 60 and $100 \mu \mathrm{m}$ ) showing in few cases irregular boundaries. Besides, most of the crystals present a clear core and rim texture (Fig. 13b) which represents variable $\mathrm{Y}$ and $\mathrm{U}$ contents : the core is $\mathrm{Y}$ and $\mathrm{U}$-poor $\left(\mathrm{Y}_{2} \mathrm{O}_{3}\right.$ between 0.3 and 1.6 wt $\%$ and $\mathrm{UO}_{2}$ between 0.2 and $\left.0.8 \mathrm{wt} \%\right)$ whereas the rim is $\mathrm{Y}$ and $\mathrm{U}$-rich $\left(\mathrm{Y}_{2} \mathrm{O}_{3}\right.$ between 1.7 and $4.2 \mathrm{wt} \%$ and $\mathrm{UO}_{2}$ up to $3.7 \mathrm{wt} \%$ ).

Thirty two analyses have been performed in the different domains of the monazite

661 grains. ${ }^{208} \mathrm{~Pb} /{ }^{232} \mathrm{Th}$ analyses yielded ages between $14.9 \pm 0.5$ and $16.4 \pm 0.5 \mathrm{Ma}$, with a 662 weighted mean age at $15.7 \pm 0.2 \mathrm{Ma}(\mathrm{MSWD}=4,1 ; \mathrm{N}=32)$. All ages appear always 663 concordant with the ${ }^{206} \mathrm{~Pb} /{ }^{238} \mathrm{U}$ ages (Fig. 13c). The U-Pb ages are mostly discordant and 664 define a linear trend crosscutting the Concordia at $15.1 \pm 0.2 \mathrm{Ma}$ in a Tera Wasserburg 665 diagram (Fig. 13d). This suggests a slight common Pb contamination and the large uncertainty 666 of the ${ }^{207} \mathrm{~Pb} /{ }^{235} \mathrm{U}$ ages due to the very low ${ }^{207} \mathrm{~Pb}$ content in young monazite. For this reason, 667 only ${ }^{208} \mathrm{~Pb} /{ }^{232} \mathrm{Th}$ ages are considered here (see details in analytical methods). The scattering of the ${ }^{208} \mathrm{~Pb} /{ }^{232} \mathrm{Th}$ ages (high MSWD) is broadly correlated to the core 669 to rim zonation, the $\mathrm{Y}$ and $\mathrm{U}$-poor cores yielding older ages than the $\mathrm{Y}$ and U-rich rims (Fig. 670 13b). However, the small difference between the ages measured in the cores and in the rim of 671 the monazite grains (less than 1.5 Ma) does not enable a clear distinction between two age 672 groups. Because i) the monazite is well known to be an efficient chronometer in dating the 
673 high temperature metamorphic processes, and ii) no inheritance (suggesting the recording of

674 older metamorphic event) has been observed, these results clearly establish a Langhian age

675 for the partial melting event that affected the infrastructure of Ikaria Island.

676

677

678 8. Discussion

679

680

8.1. An overall top-to-the-N sense of shear as the main deformation record

681

682

The whole tectonometamorphic succession of Ikaria is pervasively affected by top-to-

the-N to -NNE ductile deformation whose intensity increases toward the top of the structure

684 (Figs. 6f and 14a). While the deepest parts of the tectonometamorphic succession exhibits rather symmetrical deformation dominated by flattening, top-to-the- $\mathrm{N}$ shearing deformation shows a large-scale strain gradient toward the Fanari shear zone along which most of the strain is concentrated, with an upward evolution toward a more top-to-the-NNE kinematics

(Fig. 5). Characterized by a subordinate top-to-the-NNE strain gradient, the Agios-Kirykos shear zone is furthermore responsible for a $50{ }^{\circ} \mathrm{C}$ gap of normal sense, as retrieved by RSCM analyses (Fig. 12). These embedded gradients are accompanied by greenschist-facies retrogression gradients quite obvious at the scale of the outcrop or hand-specimen (Fig. 7).

692 Crossing the ductile to brittle transition, the Fanari shear zone has even recorded increments 693 of motion in brittle conditions responsible for the development of thick cataclasite bodies 694 (Figs. 3 and 9). The direction of ductile stretching and markers of later brittle extensional motions on the detachment planes show a continuum of NNE-SSW stretching and top-to-the-

696 NNE shearing, consistent, in a broad sense, with extensional direction in both metamorphic 697 and sedimentary rocks (Fig. 11). This evolution is interpreted as an evidence of continuous 
stretching from middle to upper crustal levels through the ductile-brittle transition and continuous shearing along a major detachment localizing deformation.

Low-temperature geochronology pointed out a clear northward younging of ZFT ages $(10.3 \pm 0.3$ to $7.1 \pm 0.3 \mathrm{Ma})$ and AFT ages $(8.4 \pm 0.8$ to $5.9 \pm 0.8 \mathrm{Ma})$ consistent with an overall top-to-the-N unroofing with apparent slip-rates over the Fanari detachment of 10-8 km/Ma (Fig. 14b; Kumerics et al., 2005). U-Th/He analyses on apatite for both flanks of the dome yielded similar 6 Ma ages. Motion over the Fanari detachment seems stop near 6 Ma. These ages constrain, in turn, the maximum age for the onset of passive "folding" of the Fanari detachment plane around the dome, which postdates the last brittle motions of the detachment and even the brittle normal faulting that affects sediments.

A progressive rotation of the stretching and shearing direction is observed from the core to the outer flanks of the domes (Fig. 5). As suggested by the structural study, the shearing strain has progressively localized through time upward from a distributed flow, recorded in the amphibolite-facies conditions, to mylonites, ultramylonites and then cataclasites in the vicinity of Fanari detachment (Figs. 3 and 9). Accordingly, the N-S trending lineation preserved in the core is older than the NNE-SSW trending one at the top along the main shear zones. The core of the dome has therefore rotated $35^{\circ}$ counterclockwise during its exhumation before the final doming that seems to be the latest event recorded on Ikaria. This late event tends to confer to the dome the geometry of an a-type dome where the stretching direction is parallel to the dome axis (Jolivet et al., 2004a) and which can suggests an oblique component of shearing during doming (Le Pourhiet et al., 2012). A significant component of E-W shortening is currently recorded in the deformation of the northern Aegean domain as a result of westward motion of Anatolia along the North Anatolian Fault (NAF) (e.g. Le Pichon and Kreemer, 2010). If the NAF has reached the northern Aegean some $6 \mathrm{Ma}$ ago as a localized crustal-scale fault zone (Armijo et al., 1999; Melinte-Dobrinescu et al., 
723

724

725

726

727

728

729

730

731

732

733

734

735

736

737

738

739

740

741

742

743

744

745

746

747

38

2009), it has been suggested that dextral movements has been active since $12 \mathrm{Ma}$ (Sengör et al., 2005). In the field, consequences of an E-W shortening are clearly recorded in the northern Cyclades, all the way to western Turkey (Angelier, 1976; Buick, 1991; Bozkurt and Park, 1997; Ring et al., 1999; Avigad et al., 2001; Menant et al., 2013). This context, showing a combination of exhumation, strike-slip and contemporaneous E-W shortening and N-S crustal stretching, suggests a component of transtension during the last evolution stages (Le Pourhiet et al., 2012; Fossen et al., 2013). This oblique component fits the hypothesis of a left-lateral transfer zone from the Menderes massif to the Cyclades proposed by Ring et al. (1999) and recently reassessed by Gessner et al. (2013). Detailed studies on the timing of the formation of stretching directions across the dome coupled with the timing of doming are necessary to go any further.

\subsection{Eastern extension of the North Cycladic Detachment System}

(1)

Obvious structural and metamorphic similarities of the series of detachments from Andros to Mykonos, with coeval top-to-the-N to -NNE kinematics, led Jolivet et al. (2010) to mechanically merge them in a single crustal-scale extensional structure, called NCDS. A probable correlation of the Fanari detachment of Kumerics et al. (2005) with the NCDS was even proposed (Jolivet et al., 2010). The existence on Ikaria of two detachments, one purely ductile and the other evolving from ductile to brittle conditions and the presence of the synkinematic granite piercing through the dome are indeed reminiscent of the anatomy of the NCDS as described on Andros, Tinos and Mykonos (Jolivet et al., 2010). On Tinos (e.g. Jolivet and Patriat, 1999; Jolivet et al., 2004a; Brichau et al., 2007) as well as on Mykonos (e.g. Faure et al., 1991; Lecomte et al., 2010; Denèle et al., 2011; Menant et al., 2013), 
748 increments of ductile and then brittle deformation are recorded by synkinematic intrusions

749 emplaced into the main extensional shear zones. The Tinos Detachment is mostly ductile and

750 is pierced by the Tinos intrusion. Conversely, the Livada Detachment shows ductile then

751 brittle deformation and affects the Tinos intrusion (Brichau et al., 2007). This last detachment

752 is then pierced by the Mykonos intrusion. The more superficial Mykonos Detachment that 753 clearly post-dates all intrusions, operated only in purely brittle conditions and carries syn754 extension sediments (e.g. Lecomte et al., 2010; Menant et al., 2013). These three detachments 755 that operate sequentially form the NCDS. A similar evolution is observed on Ikaria. 756 Exclusively operating in the ductile field, the Agios-Kirykos shear zone is later cut down757 section by the Fanari detachment that evolves from ductile to brittle and even controls the 758 deposition of syn-tectonic sediments in the hangingwall.

759 Along with the current lack of precise time-constraints on synkinematic minerals, 760 timing of extensional deformation onset is still unclear on Ikaria. If partial melting occurred at 761 ca. $15.5 \mathrm{Ma}$, as showed in this study, the signification of the 25-17 K/Ar ages on hornblende 762 (Altherr et al., 1982) are questioned. These ages may reflect either Ar inheritance from an 763 earlier tectonometamorphic event or simply excess argon (i.e. extraneous argon), as suggested 764 by the strong scattering of these ages. Then, onset of extension might starts at or just after ca. 765 15.5 Ma. The 12-9 Ma K/Ar and Ar/Ar ages obtained on fabric-forming white-micas and 766 biotite are believed to record either a fast cooling or last recrystallizations during 767 mylonitization (see compilation on Fig. 14b; Altherr et al., 1982; Kumerics et al., 2005). In 768 parallel, the three intrusions (Raches, Karkinagrion and Xylosyrtis) that crystallized at 14-13 769 Ma therefore synkinematically emplace within the Fanari shear zone (U-Pb on zircon; Bolhar 770 et al., 2010; Laurent et al., 2015). Intrusions all underwent a common fast cooling to 771 temperatures close to the ductile to brittle transition (Stöckhert et al., 1999; Imber et al., 2001) 772 at ca. $10 \mathrm{Ma}$ (K/Ar and Ar/Ar on micas; Altherr et al., 1982; Kumerics et al., 2005). Being 
773

774

775

776

777

778

779

780

781

782

783

784

785

786

787

788

789

790

791

792

793

794

795

796

797

only active in the ductile field, the Agios-Kirykos therefore probably ceased to be active some $10 \mathrm{Ma}$ ago. Displacement and further strain localization were thus transferred to the Fanari shear zone, responsible for the final exhumation, in the ductile and then the brittle field. The last exhumation stages were characterized by fast $\left(100-80{ }^{\circ} \mathrm{C} / \mathrm{Ma}\right)$ cooling rates and ended at around $6 \mathrm{Ma}$ (Fig. 14b; FT and U-Th/He on zircon and apatite; Kumerics et al., 2005). As a comparison, crystallization and cooling of the Mykonos pluton occurred between 13.5 Ma and $9 \mathrm{Ma}$ as a result of the fast exhumation related to the activity of the Livada and Mykonos detachments (e.g. Brichau et al., 2008; Lecomte et al., 2010; Jolivet et al., 2010). Lowtemperature ages even suggest that motions over the Fanari detachment continued until $6 \mathrm{Ma}$ and are thus the last top-to-the-N to -NNE detachment active in the Aegean domain. These similarities in terms of geometries, kinematics and timing of the Ikaria detachments and the various branches of the NCDS confirm the proposed eastward extension of the NCDS all the way to the eastern end of Ikaria in the Agios-Kirykos and Fanari shear zones (Fig. 15).

Similarly to Mykonos, the detachment system of Ikaria, does not exhume HP-LT metamorphic rocks belonging to the Cycladic Blueschists unit, at variance with Tinos and Andros. Indeed, along with the structural position and the lithostratigraphic succession, the apparent lack of any $\mathrm{H} P$-LT imprint either in Ikaria and Agios-Kirykos units precludes correlations with the Cycladic Blueschists unit. The Ikaria and Agios-Kirykos units are characterized by the same monotonous lithologies and a similar $80-100{ }^{\circ} \mathrm{C} / \mathrm{km}$ thermal field gradient, it is proposed that both units were equilibrated along a single, warm gradient rooting in partially-molten rocks.

Correlated with the Upper Cycladic unit, in a broad sense, the Fanari unit reworks large amount of Pelagonian detritus shed into the extensional basins (Photiades, 2002a). While deposition of sediments on the Upper Cycladic unit started around 23 Ma throughout the Aegean domain (Angelier et al., 1976; Sánchez-Gómez et al., 2002; Kuhlemann et al., 
2004), sediments preserved on Ikaria are attributed to Late Oligocene to Early Pliocene

799 (Papanikolaou, 1978; Photiades, 2002a; 2002b). This rather recent deposition age is consistent

804

805

806

807

808

809

810

with last denudation ages ascribed to last extensional motions over the Fanari detachment (Kumerics et al., 2005), which may be responsible for maintaining a significant tectonic subsidence.

8.3. Definition of the Ikaria MCC and the central Aegean HT zone
The structure of Ikaria is composed of two main parts separated by a detachment system consisting in shallow-dipping extensional ductile to brittle shear zones connecting surficial to mid-crustal levels (e.g. Fig. 2). The bulk finite architecture of the footwall consists in an elongated structural dome roofed by a partly eroded mylonite, ultramylonite and cataclasite carapace (Fig. 4). This geometrical dome is paired with a fairly concentric distribution metamorphic zones of decreasing grade from migmatites and $625^{\circ} \mathrm{C}$ in the core to $390{ }^{\circ} \mathrm{C}$ in the externals parts (Fig. 12). The dome flanks display 500-m thick strain gradient evolving upward to mylonites characterized by the uniformity of shear sense from one limb to the other. They are partially overprinted by cataclasites and fault-rocks in the Fanari detachment zone (Figs. 3 and 9). The detachment itself is marked by a clear-cut fault plane carrying evidences for large-scale displacements in the brittle field (Fig. 9). The hangingwall unit, exclusively composed sediments, is only characterized by brittle deformation (Fig. 10). Following this description, Ikaria dome shares all attributes of a typical migmatite-cored MCC (see Platt et al., 2014, for review) firstly described in the Basin and Range of western United States (Davis and Coney, 1979; Crittenden et al., 1980; Wernicke, 1981, 1985), and then in other Alpine (e.g. Lister et al., 1984; Dewey, 1988; Gautier et al., 1993; Gautier and 
823

824

826

Brun, 1994; Jolivet and Patriat, 1999; Vanderhaeghe, 2004) and Variscan or Caledonian orogenic belts (e.g. Norton, 1986; Andersen et al., 1991).

Partial melting is a key factor that controls the strength of the continental crust. The recent discovery of migmatites in the infrastructure of the Ikaria MCC dome may have important implications for the behavior of the Hellenic continental crust during OligoMiocene extension. Several high-grade gneiss and migmatite massifs have already been described in the Aegean realm. However, most of these occurrences of HT rocks are basement rocks inherited from ancient tectonometamorphic events. An early Paleozoic HT event is known in the Menderes (e.g. Gessner et al., 2004) and in the East of the Aegean Sea, particularly on Ikaria (Kumerics et al., 2005; Ring et al., 2007). There, a ca. 460 Ma age retrieved form a pegmatite dyke may reflect a minimum age for HT metamorphism (Kumerics et al., 2005). A Variscan inheritance is also well described in the Cycladic basement unit in the Southern Cyclades (e.g. Henjes-Kunst and Kreuzer, 1982; Andriessen et al., 1987; Keay and Lister, 2002). On these islands, a ca. 320 Ma granite and amphibolite facies gneisses are partially overprinted by the Eocene HP imprint (e.g. Henjes-Kunst and Kreuzer, 1982; Andriessen et al., 1987; Keay and Lister, 2002; Huet et al., 2009; Augier et al., 2015). The only Oligo-Miocene migmatites crop out in the core of the Naxos MCC, the first that has been described in the Aegean domain (e. g. Lister et al., 1984). There, the age of the partial melting is quite constrained by $\mathrm{U}-\mathrm{Pb}$ analyses on zircon yielding series of ages ranging from 21 to 17 Ma (Keay et al., 2001). The age of migmatites recently discovered on Ikaria is therefore of prime importance. In this study, pioneer $\mathrm{U}-\mathrm{Th}-\mathrm{Pb}$ analyses on monazites from a leucosome of the migmatites yielded an age of $15.7 \pm 0.2 \mathrm{Ma}$ (Fig. 13). This result falls in the same agerange than the recent $\mathrm{U}-\mathrm{Pb}$ age on zircon ascribed to the Karkinagrion S-type granite (Bolhar et al., 2010) together with closely associated migmatites (Laurent et al., 2015). Clearly associated with the same large scale partial melting event that affected the Hellenic 
continental crust, anatexis at the latitude of Ikaria appears slightly younger than further south on Naxos. Along with Naxos, Mykonos and Ikaria, HT MCCs all cluster in the central part of the Aegean domain. It is here proposed to define the central Aegean HT zone as a large-scale extensional tectonic window of high-grade, partially-molten rocks (Fig. 15), of Early-Middle Miocene age (Keay et al., 2001; this study) (Fig. 15). There, intense stretching leads to the complete tectonic omission of the Cycladic Blueschists unit that is observed in colder MCCs further west in Syros, Andros or Tinos (e.g. Trotet et al., 2001a; Mehl et al., 2007), to the east in Samos (e.g. Ring et al., 1999) or to the south in Ios, Folegandros and Sikinos (e.g. Huet et al., 2009; Augier et al., 2015). This gradient of finite stretching toward the center and east of the Cyclades is attested by the joint evolution of the topography, the crustal thickness and the first order transition from brittle to ductile deformation from marginal areas to the center of the Aegean domain (e.g. Jolivet et al., 2010). Uprise of partially-molten materials in-between less-extended Cycladic Blueschists unit evokes crustal-scale equivalents of the scar folds that result from "boudins"' separation in the process of boudinage (Tirel et al., 2008). This simple model should however be adapted as three distinctive detachment bounding smaller-scale MCCs are currently observed (Fig. 15). The NCDS (Jolivet et al., 2010) exhumes Andros, Tinos, Mykonos and Ikaria in the north while the NDP exhumes Naxos and Paros in the center (Buick, 1991; Gautier et al., 1993; Vanderhaeghe, 2004; Duchêne et al., 2006; Kruckenberg et al., 2011). Both are associated with top-to-the-N shear. Finally, further southwest, the alignment of Kea, Kythnos and Serifos shows another row of small-scale domes exhumed by the top-to-the-SW WCDS (Grasemann et al., 2012). If top-to-the-S criteria on Ios and Sikinos are related to a thrust (Huet et al., 2009; Augier et al., 2015) and not to a detachment (Vandenberg and Lister, 1996; Forster and Lister, 1999; Thomson et al., 2009; Ring et al., 2011) then extensional top-to-the-N shearing is systematically observed from north to south of the central Aegean (Fig. 15). This result contrasts with the more 
873 symmetric deformation recognized in marginal areas, where symmetrically arranged

874 detachment systems depict more bivergent extensional systems either to the west (Grasemann

875 et al., 2012) or east in Samos (Ring et al., 1999) or in the Menderes massif (Hetzel et al.,

876 1995b; Gessner et al., 2001). A correlation between the amount of stretching of the crust and

877 the degree of non-coaxiality is therefore proposed. Just as the Tyrrhenian or the Alboran back-

878 arc systems, the causes of this regional-scale non-coaxial extension in the Aegean back-arc

879 domain is a first-order question that is outside the focus of this paper but may pertain to the 880 interactions between the upper plate, the retreating subducting slab and the flowing 881 asthenospheric mantle (Jolivet et al., 2009; Sternai et al., 2014).

882

883

884

9. Conclusions

885

886

Although Ikaria is one of the largest Aegean islands and paves the way between the

Cyclades and the Menderes massif, its geology and tectonic evolution remain poorly understood since recent studies lead to very conflicting maps and interpretations. This paper reports a detailed 3D study of the geometry and the thermal structure of Ikaria. The structural study shows that the HT-LP foliation is arched, forming a NE-SW trending structural dome cored by partially molten rocks and intruded by late intrusive granitic bodies. Lineation shows

892 a N-S to NNE-SSW ductile stretching associated with an overall top-to-the-N to -NNE sense 893 of shear. Final exhumation of the dome was completed by Miocene extensional system made 894 of two main top-to-the-N to -NNE shear zones, operating in the ductile and then the brittle 895 fields. The thermal structure revealed by the RSCM approach strengthened the subdivision of 896 the metamorphic succession in two main metamorphic units (Ikaria and Agios-Kirykos units) 897 with an upward decrease of maximum temperature, separated by the Agios-Kirykos shear 
898

899

900

901

902

903

904

905

906

907

908

909

910

911

912

913

914

915

916

917

918

919

920

References proposed.

zone. The Fanari detachment permits to juxtapose the sedimentary Fanari unit directly on metamorphic rocks. The distribution of RSCM temperatures within the dome and the presence of migmatites of ca. 15.5 Ma age in the western part of the island fit the description of a HT MCC such as Naxos or Mykonos. The proposed tectono-metamorphic evolution of the dome is consistent with the evolution of the northern Aegean area controlled by the eastern extension of the NCDS. Definition of Ikaria as a HT MCC allows the definition of the geographic extent of the central Aegean HT zone associated with strictly asymmetric top-tothe-N ductile shearing and an Early-Middle Miocene partial melting event. A correlation between the amount of stretching of the crust and the degree of non-coaxiality is therefore

\section{Acknowledgements}

Uwe Ring and Berhnard Grasemann are thanked for their constructive comments and suggestions that improved the manuscript. This work has received funding from the European Research Council (ERC) under the Seventh Framework Programme of the European Union (ERC Advanced Grant, grant agreement No 290864, RHEOLITH) as well as Institut Universitaire de France. It is a contribution of the Labex VOLTAIRE. The authors are grateful to S. Janiec and J.G. Badin (ISTO) for the preparation of thin sections. 
922

923

924

925

926

927

928

929

930

931

932

933

934

935

936

937

938

939

940

941

942

943

944

945

946

Altherr, R., Kreuzer, H., Lenz, H., Wendt, I., Harre, W. \& Dürr, S. (1994). Further Evidence for a Late Cretaceous Low-pressure high-temperature Terrane in the Cyclades, Greece Petrology and Geochronology of Crystalline Rocks from the Islands of Donoussa and Ikaria. Chemie Der Erde 54, 319-328.

Altherr, R., Kreuzer, H., Wendt, I., Lenz, H., Wagner, G. A., Keller, J., Harre, W. \& Höhndorf, A. (1982). A Late Oligocene/Early Miocene High Temperature Belt in the AtticCycladic Crystalline Complex (SE Pelagonian, Greece). Geologisches Jahrbuch 23, 97-164.

Altherr, R., Schliestedt, M., Okrusch, M., Seidel, E., Kreuzer, H., Harre, W., Lenz, H., Wendt, I. \& Wagner, G. A. (1979). Geochronology of High-Pressure Rocks on Sifnos (cyclades, Greece). Contributions to Mineralogy and Petrology 70, 245-255.

Altherr, R. \& Siebel, W. (2002). I-type plutonism in a continental back-arc setting: Miocene granitoids and monzonites from the central Aegean Sea, Greece. Contributions to Mineralogy and Petrology 143, 397-415.

Andersen, T. B., Jamtveit, B., Dewey, J. F. \& Swensson, E. (1991). Subduction and eduction of continental crust: major mechanisms during continent-continent collision and orogenic extensional collapse, a model based on the south Norwegian Caledonides. Terra Nova 3, 303310.

Andriessen, P. A. M., Banga, G. \& Hebeda, E. H. (1987). Isotopic age study of pre-Alpine rocks in the basal units on Naxos, Sikinos and Ios, Greek Cyclades. Geologie en Mijnbouw 66, 3-14. 
948 Angelier, J. (1976). Sur l'alternance mio-plio-quaternaire de mouvements extensifs et 949 compressifs en Egée orientale: l'île de Samos (Grèce). Comptes Rendus de l'Academie des 950 Sciences de Paris 283, 463-466.

951

952 Armijo, R., Meyer, B., Hubert, A. \& Barka, A. (1999). Westward propagation of the North 953 Anatolian fault into the northern Aegean: Timing and kinematics. Geology 27, 267-270.

954

955 956

Aubouin, J. \& Dercourt, J. (1965). Sur la géologie de l’Egée: regard sur la Crète. Bulletin de la Societe Geologique de France 7, 787-821.

957

958 Augier, R., Jolivet, L., Gadenne, L., Lahfid, A. \& Driussi, O. (2015). Exhumation kinematics 959 of the Cycladic Blueschists unit and back-arc extension, insight from the Southern Cyclades 960 (Sikinos and Folegandros Islands, Greece). Tectonics 34, 152-185.

961

962 Avigad, D. \& Garfunkel, Z. (1989). Low-angle faults above and below a blueschist belt: 963 Tinos Island, Cyclades, Greece. Terra Nova 1, 182-187.

964

965 Avigad, D. \& Garfunkel, Z. (1991). Uplift and exhumation of high-pressure metamorphic 966 terrains: the example of the Cycladic blueschist belt (Aegean Sea). Tectonophysics 188, 357967372.

969 Avigad, D., Ziv, A. \& Garfunkel, Z. (2001). Ductile and brittle shortening, extension-parallel 970 folds and maintenance of crustal thickness in the central Aegean (Cyclades, Greece). 971 Tectonics 20, 277-287. 
973 Baldwin, S. L. \& Lister, G. S. (1998). Thermochronology of the South Cyclades Shear Zone, 974 Ios, Greece: effects of ductile shear in the argon partial retention zone. Journal of Geophysical 975 Research 103, 7315-7336.

976

977 Beyssac, O., Goffé, B., Chopin, C. \& Rouzaud, J. N. (2002). Raman spectra of carbonaceous 978 material in metasediments: a new geothermometer. Journal of Metamorphic Geology 20, 859979 871.

980

981 Blake, M. C., Bonneau, M., Geyssant, J., Kienast, J. R., Lepvrier, C., Maluski, H. \& 982 Papanikolaou, D. (1981). A geologic reconnaissance of the Cycladic blueschist belt, Greece. 983 Geological Society of America Bulletin 92, 247-254.

984

985 Bolhar, R., Ring, U. \& Allen, C. M. (2010). An integrated zircon geochronological and 986 geochemical investigation into the Miocene plutonic evolution of the Cyclades, Aegean Sea, 987 Greece: Part 1: Geochronology. Contributions to Mineralogy and Petrology 160, 719-742.

988

989 Bonneau, M. (1984). Correlation of the Hellenic nappes in the south-east Aegean and their 990 tectonic reconstruction. In: Dixon, J. E., Robertson, A. H. F. (Eds.), The Geological Evolution 991 of the Eastern Mediterranean. Geological Society, London, Special Publications 17, 517-527. 992

993 Bonneau, M. \& Kienast, J. R. (1982). Subduction, collision et schistes bleus: exemple de 994 l’Egée, Grèce. Bulletin de la Societe Geologique de France 24, 785-791. 
Bozkurt, E. (2007). Extensional v. contractional origin for the southern Menderes shear zone,

SW Turkey: tectonic and metamorphic implications. Geological Magazine 144, 191-210.

998

999

Bozkurt, E. \& Park, R. G. (1997). Evolution of a mid-Tertiary extensional shear zone in the

southern Menderes massif, western Turkey. Bulletin de la Societe Geologique de France 168,

$10013-14$.

1002

1003

Bozkurt, E., Satir, M. \& Bugdaycioglu, C. (2011). Surprisingly young Rb/Sr ages from the

1004

Simav extensional detachment fault zone, northern Menderes Massif, Turkey. Journal of

1005 Geodynamics 52, 406-431.

1006

1007 Brandon, M. T., Roden-Tice, M. K. \& Garver, J. I. (1998). Late Cenozoic exhumation of the

1008 Cascadia accretionary wedge in the Olympic Mountains, northwest Washington State.

1009 Geological Society of America Bulletin 110, 985-1009.

1010

1011 Brichau, S., Ring, U., Carter, A., Bolhar, R., Monié, P., Stockli, D. \& Brunel, M. (2008).

1012 Timing, slip rate, displacement and cooling history of the Mykonos detachment footwall,

1013 Cyclades, Greece, and implications for the opening of the Aegean Sea basin. Journal of the

1014 Geological Society 165, 263-277.

1015

1016 Brichau, S., Ring, U., Carter, A., Monié, P., Bolhar, R., Stockli, D. \& Brunel, M. (2007).

1017 Extensional faulting on Tinos Island, Aegean Sea, Greece: How many detachments?

1018 Tectonics 26, TC4009.

1019 
1020

1021

1022

1023

1024

1025

1026

1027

1028

1029

1030

1031

1032

1033

1034

1035

1036

1037

1038

1039

1040 Crittenden, M. D., Coney, P. J. \& Davis, G. H. (1980). Cordilleran metamorphic core 1041 complexes. Geological Society of America Memoirs 153, 271-279.

Brichau, S., Thomson, S. \& Ring, U. (2010). Thermochronometric constraints on the tectonic evolution of the Serifos detachment, Aegean Sea, Greece. International Journal of Earth Sciences 99, 379-393.

Brunn, J. H., Argyriadis, I., Ricou, L. E., Poisson, A., Marcoux, J. \& de Graciansky, P. C. (1976). Eléments majeurs de liaison entre Taurides et Hellénides. Bulletin de la Societe Geologique de France 18, 481-497.

Buick, I. S. (1991). The late Alpine evolution of an extensional shear zone, Naxos, Greece. Journal of the Geological Society, London 148, 93-103.

Buick, I. S. \& Holland, T. J. B. (1989). The P-T-t path associated with crustal extension, Naxos, Cyclades, Greece. Geological Society, London, Special Publications 43, 365-369.

Cherniak, D. J. \& Watson, E. B. (2001). Pb diffusion in zircon. Chemical Geology 172, 5-24.

Corti, G., Bonini, M., Conticelli, S., Innocenti, F., Manetti, P. \& Sokoutis, D. (2003). Analogue modelling of continental extension: a review focused on the relations between the patterns of deformation and the presence of magma. Earth-Science Reviews 63, 169-247. 
1043 Cruz, M. J., Cunha, J. C., Merlet, C. \& Sabaté, P. (1996). Dataçao pontual das monazitas da

1044 regiao de Itambe, Bahia, através da microssonda electrônica. XXXIX Congresso Brasileiro de 1045 Geologia, pp. 206-209.

1046

1047 Davis, G. H. \& Coney, P. J. (1979). Geologic development of the Cordilleran metamorphic 1048 core complexes. Geology 7, 120-124.

1049

1050 Delvaux, D. \& Sperner, B. (2003). New aspects of tectonic stress inversion with reference to 1051 the TENSOR program. In: Nieuwland, D. A. (Ed.), New Insights into Structural Interpretation 1052 and Modelling. Geological Society, London, Special Publications 212, 75-100.

1053

1054 Denèle, Y., Lecomte, E., Jolivet, L., Lacombe, O., Labrousse, L., Huet, B. \& Le Pourhiet, L. 1055 (2011). Granite intrusion in a metamorphic core complex: The example of the Mykonos 1056 laccolith (Cyclades, Greece). Tectonophysics 501, 52-70.

1057

1058 Dewey, J. F. (1988). Extensional collapse of orogens. Tectonics 7, 1123-1139.

1059

1060 Didier, A., Bosse, V., Boulvais, P., Bouloton, J., Paquette, J. L., Montel, J. M. \& Devidal, J.

1061 L. (2013). Disturbance versus preservation of U-Th-Pb ages in monazite during fluid-rock 1062 interaction: textural, chemical and isotopic in situ study in microgranites (Velay Dome, 1063 France). Contributions to Mineralogy and Petrology 165, 1051-1072.

1064

1065 Didier, A., Bosse, V., Cherneva, Z., Gautier, P., Georgieva, M., Paquette, J. L. \& Gerdjikov, I. 1066 (2014). Syn-deformation fluid-assisted growth of monazite during renewed high-grade 
1067

1068

1069

1070

1071

1072

1073

1074

1075

1076

1077

1078

1079

1080

1081

1082

1083

1084

1085

1086

1087

1088

1089

1090

metamorphism in metapelites of the Central Rhodope (Bulgaria, Greece). Chemical Geology 381, 206-222.

Duchêne, S., Aïssa, R. \& Vanderhaeghe, O. (2006). Pressure-Temperature-Time Evolution of Metamorphic Rocks from Naxos (Cyclades, Greece): Constraints from Thermobarometry and Rb/Sr dating. Geodinamica Acta 19, 299-313.

Faccenna, C., Piromallo, C., Crespo-Blanc, A., Jolivet, L. \& Rossetti, F. (2004). Lateral slab deformation and the origin of the western Mediterranean arcs. Tectonics 23, TC1012.

Farley, K. A. (2000). Helium diffusion from apatite: General behavior as illustrated by Durango fluorapatite. Journal of Geophysical Research 105, 2903-2914.

Faure, M., Bonneau, M. \& Pons, J. (1991). Ductile deformation and syntectonic granite emplacement during the late Miocene extension of the Aegea (greece). Bulletin de la Societe Geologique de France 162, 3-11.

Fletcher, I. R., McNaughton, N. J., Davis, W. J. \& Rsmussen, B. (2010). Matrix effects and calibration limitations in ion probe $\mathrm{U}-\mathrm{Pb}$ and $\mathrm{Th}-\mathrm{Pb}$ dating of monazite. Chemical Geology $270,31-44$.

Forster, M. \& Lister, G. (2009). Core-complex-related extension of the Aegean lithosphere initiated at the Eocene-Oligocene transition. Journal of Geophysical Research 114, B02401. 
Fossen, H., Teyssier, C. \& Whitney, D. L. (2013). Transtensional folding. Journal of

1092 Structural Geology 56, 89-102.

1093

1094 Gabalda, S., Beyssac, O., Jolivet, L., Agard, P. \& Chopin, C. (2009). Thermal structure of a 1095 fossil subduction wedge in the Western Alps. Terra Nova 21, $28-34$.

1096

1097 Gasquet, D. et al. (2010). Miocene to Messinian deformation and hydrothermalism in the Lauzière Massif (French Western Alps): New U-Th-Pb and Argon ages. Bulletin de la Societe Geologique de France 181, 227-241.

1100

1101 Gautier, P. \& Brun, J.-P. (1994). Ductile crust exhumation and extensional detachments in the 1102 central Aegean (Cyclades and Evvia Islands). Geodinamica Acta 7, 57-85.

1103

1104 Gautier, P., Brun, J.-P. \& Jolivet, L. (1993). Structure and kinematics of upper cenozoic 1105 extensional detachment on Naxos and Paros (cyclades islands, Greece). Tectonics 12, 118011061194.

1107

1108 Gessner, K., Collins, A. S., Ring, U. \& Güngör, T. (2004). Structural and thermal history of 1109 poly-orogenic basement: U-Pb geochronology of granitoid rocks in the southern Menderes 1110 Massif, Western Turkey. Journal of the Geological Society, London 161, 93-101.

1112 Gessner, K., Gallardo, L. A., Markwitz, V., Ring, U. \& Thomson, S. N. (2013). What caused 1113 the denudation of the Menderes Massif: Review of crustal evolution, lithosphere structure, 1114 and dynamic topography in southwest Turkey. Gondwana Research 24, 243-274. 
1116 Gessner, K., Ring, U., Johnson, C., Hetzel, R., Passchier, C. W. \& Güngör, T. (2001). An

1117 active bivergent rolling-hinge detachment system: Central Menderes metamorphic core 1118 complex in western Turkey. Geology 29, 611-614.

1119

1120 Glodny, J. \& Hetzel, R. (2007). Precise U-Pb ages of syn-extensional Miocene intrusions in 1121 the central Menderes Massif, western Turkey. Geological Magazine 144, 235.

1122

1123 Grasemann, B. \& Petrakakis, K. (2007). Evolution of the Serifos Metamorphic Core

1124 Complex. In: Lister, G., Foster, M., Ring, U. (Eds.), Inside the Aegean Core Complexes.

1125 Journal of the Virtual Explorer 27.

1126

1127 Grasemann, B., Schneider, D. A., Stöckli, D. F. \& Iglseder, C. (2012). Miocene bivergent crustal extension in the Aegean: Evidence from the western Cyclades (Greece). Lithosphere 4, 23-39.

1131 Groppo, C., Forster, M., Lister, G. \& Compagnoni, R. (2009). Glaucophane schists and 1132 associated rocks from Sifnos (Cyclades, Greece): New constraints on the P-T evolution from oxidized systems. Lithos 109, 254-273.

1134

1135 Grove, M. \& Harrison, T. M. (1996). Ar-40* diffusion in Fe-rich biotite. American 1136 Mineralogist 81, 940-951.

1138 Harrison, T. M. (1981). Diffusion of 40Ar in hornblende. Contributions to Mineralogy and 1139 Petrology 78, 324-331. 
1141 Harrison, T. M., Célérier, J., Aikman, A. B., Hermann, J. \& Heizler, M. T. (2009). Diffusion

1142 of 40Ar in muscovite. Geochimica et Cosmochimica Acta 73, 1039-1051.

1143

1144 Henjes-Kunst, F. \& Kreuzer, H. (1982). Isotopic dating of pre-Alpidic rocks from the island 1145 of Ios (Cyclades, Greece). Contributions to Mineralogy and Petrology 80, 245-253.

1146

1147 Hetzel, R., Passchier, C. W., Ring, U. \& Dora, Ö. O. (1995a). Bivergent extension in orogenic 1148 belts: the Menderes massif (southwestern Turkey). Geology 23, 455-458.

1149

1150 Hetzel, R., Ring, U., Akal, C. \& Troesch, M. (1995b). Miocene NNE-directed extensional 1151 unroofing in the Menderes Massif, southwestern Turkey. Journal of the Geological Society, 1152 London 152, 639-654.

1153

1154 Hezel, D. C., Kalt, A., Marschall, H. R., Ludwig, T. \& Meyer, H.-P. (2011). Major-element 1155 and $\mathrm{Li}, \mathrm{Be}$ compositional evolution of tourmaline in an S-type granite-pegmatite system and 1156 its country rocks: an example from Ikaria, Aegean Sea, Greece. The Canadian Mineralogist $1157 \quad 49,321-340$.

1158

1159 Huet, B., Labrousse, L. \& Jolivet, L. (2009). Thrust or detachment? Exhumation processes in 1160 the Aegean: Insight from a field study on Ios (Cyclades, Greece). Tectonics 28, TC3007.

1162 Iglseder, C., Grasemann, B., Rice, A. H. N., Petrakakis, K. \& Schneider, D. A. (2011). 1163 Miocene south directed low-angle normal fault evolution on Kea Island (West Cycladic 1164 Detachment System, Greece). Tectonics 30, TC4013. 
1166 Iglseder, C., Grasemann, B., Schneider, D. A., Petrakakis, K., Miller, C., Klötzli, U. S., Thöni,

1167 M., Zámolyi, A. \& Rambousek, C. (2009). I and S-type plutonism on Serifos (W-Cyclades,

1168 Greece). Tectonophysics 473, 69-83.

1169

1170 Imber, J., Holdsworth, R. E., Butler, C. A. \& Strachan, R. A. (2001). A reappraisal of the

1171 Sibson-Scholz fault zone model: The nature of the frictional to viscous ("brittle-ductile")

1172 transition along a long-lived, crustal-scale fault, Outer Hebrides, Scotland. Tectonics 20, 6011173624.

1174

1175 Jackson, S. E., Pearson, N. J., Griffin, W. L. \& Belousova, E. A. (2004). The application of 1176 laser ablation-inductively coupled plasma-mass spectrometry to in situ U-Pb zircon 1177 geochronology. Chemical Geology 211, 47-69.

1178

1179 Janots, E., Berger, A. \& Gnos, E. (2012). Constraints on fluid evolution during 1180 metamorphism from U-Th-Pb systematics in Alpine hydrothermal monazite. Chemical 1181 Geology 326-327, 61-71.

1182

1183 Jansen, J. B. H. \& Schuiling, R. D. (1976). Metamorphism on Naxos-Petrology and 1184 geothermal gradients. American Journal of Science 276, 1225-1253.

1185

1186 Jolivet, L. et al. (2013). Aegean tectonics: Strain localisation, slab tearing and trench retreat.

1187 Tectonophysics 597, 1-33.

1188 
1189 Jolivet, L., Augier, R., Faccenna, C., Negro, F., Rimmelé, G., Agard, P., Robin, C., Rossetti,

1190 F. \& Crespo-Blanc, A. (2008). Subduction, convergence and the mode of backarc extension in 1191 the Mediterranean region. Bulletin de la Societe Geologique de France 179, 525-550.

1192

1193 Jolivet, L. \& Brun, J.-P. (2010). Cenozoic geodynamic evolution of the Aegean. International 1194 Journal of Earth Sciences 99, 109-138.

1195

1196 Jolivet, L. \& Faccenna, C. (2000). Mediterranean extension and the Africa-Eurasia collision.

1197 Tectonics 19, 1095-1106.

1198

1199 Jolivet, L., Faccenna, C. \& Piromallo, C. (2009). From mantle to crust: Stretching the 1200 Mediterranean. Earth and Planetary Science Letters 285, 198-209.

1201

1202 Jolivet, L., Famin, V., Mehl, C., Parra, T., Aubourg, C., Hébert, R. \& Philippot, P. (2004a). 1203 Progressive strain localisation, boudinage and extensional metamorphic complexes, the 1204 Aegean Sea case. In: Whitney, D. L., Teyssier, C., Siddoway, C. S. (Eds.), Gneiss Domes in 1205 Orogeny. Geological Society of America Special Papers 380, 185-210.

1206

1207 Jolivet, L., Lecomte, E., Huet, B., Denèle, Y., Lacombe, O., Labrousse, L., Le Pourhiet, L. \& 1208 Mehl, C. (2010). The North Cycladic Detachment System. Earth and Planetary Science 1209 Letters 289, 87-104.

1210

1211 Jolivet, L. \& Patriat, M. (1999). Ductile extension and the formation of the Aegean Sea. In:

1212 Durand, B., Jolivet, L., Horvàth, F., Séranne, M. (Eds.), The Mediterranean Basins: Tertiary 
1213 Extension Within the Alpine Orogen. Geological Society, London, Special Publications 156, $1214 \quad 427-456$.

1215

1216 Jolivet, L., Rimmelé, G., Oberhänsli, R., Goffé, B. \& Candan, O. (2004b). Correlation of syn1217 orogenic tectonic and metamorphic events in the Cyclades, the Lycian nappes and the 1218 Menderes massif. Geodynamic implications. Bulletin de la Societe Geologique de France 175, $1219217-238$.

1220

1221 Katzir, Y., Matthews, A., Garfunkel, Z., Schliestedt, M. \& Avigad, D. (1996). The tectono1222 metamorphic evolution of a dismembered ophiolite (Tinos, Cyclades, Greece). Geological 1223 Magazine 133, 237-254.

1224

1225 Keay, S. \& Lister, G. (2002). African provenance for the metasediments and metaigneous 1226 rocks of the Cyclades, Aegean Sea, Greece. Geology 30, 235-238.

1228 Keay, S., Lister, G. \& Buick, I. (2001). The timing of partial melting, Barrovian 1229 metamorphism and granite intrusion in the Naxos metamorphic core complex, Cyclades, 1230 Aegean Sea, Greece. Tectonophysics 342, 275-312.

1232 Keiter, M., Piepjohn, K., Ballhaus, C., Lagos, M. \& Bode, M. (2004). Structural development 1233 of high-pressure metamorphic rocks on Syros island (Cyclades, Greece). Journal of Structural 1234 Geology 26, 1433-1445.

1235 
1236 Ketcham, R. A., Donelick, R. A. \& Carlson, W. D. (1999). Variability of apatite fission-track

1237 annealing kinetics: III. Extrapolation to geological time scales. American Mineralogist 84, $1238 \quad 1235-1255$.

1239

1240 Kokkalas, S. \& Aydin, A. (2013). Is there a link between faulting and magmatism in the 1241 south-central Aegean Sea? Geological Magazine 150, 193-224.

1242

1243 Kruckenberg, S. C., Vanderhaeghe, O., Ferré, E. C., Teyssier, C. \& Whitney, D. L. (2011).

1244 Flow of partially molten crust and the internal dynamics of a migmatite dome, Naxos, Greece.

1245 Tectonics 30, TC3001.

1246

1247 Kuhlemann, J., Frisch, W., Dunkl, I., Kázmér, M. \& Schmiedl, G. (2004). Miocene 1248 siliciclastic deposits of Naxos Island: geodynamic and environmental implications for the 1249 evolution of the southern Aegean Sea (Greece). In: Bernet, M., Spiegel, C. (Eds.), Detrital 1250 Thermochronology-Provenance Analysis, Exhumation, and Landscape Evolution of Mountain 1251 Belts. Geological Society of America Special Papers 378, 51-65.

1252

1253 Kumerics, C., Ring, U., Brichau, S., Glodny, J. \& Monié, P. (2005). The extensional Messaria 1254 shear zone and associated brittle detachment faults, Aegean Sea, Greece. Journal of the 1255 Geological Society 162, 701-721.

1256

1257 Lahfid, A., Beyssac, O., Deville, E., Negro, F., Chopin, C. \& Goffé, B. (2010). Evolution of 1258 the Raman spectrum of carbonaceous material in low-grade metasediments of the Glarus Alps 1259 (Switzerland). Terra Nova 22, 354-360. 
1261 Laurent, V., Beaudoin, A., Jolivet, L., Arbaret, L., Augier, R., Rabillard, A. \& Menant, A. 1262 (2015). Interrelations between extensional shear zones and synkinematic intrusions: The example of Ikaria Island (NE Cyclades, Greece). Tectonophysics 651-652, 152-171.

1264

1265

Lecomte, E., Jolivet, L., Lacombe, O., Denèle, Y., Labrousse, L. \& Le Pourhiet, L. (2010).

1266 Geometry and kinematics of Mykonos detachment, Cyclades, Greece: Evidence for slip at 1267 shallow dip. Tectonics 29, TC5012.

1268

1269

Lee, J. \& Lister, G. S. (1992). Late Miocene ductile extension and detachment faulting, Mykonos, Greece. Geology 20, 121-124.

1271

1272 Le Pichon, X. \& Angelier, J. (1979). The Hellenic arc and trench system: a key to the 1273 neotectonic evolution of the eastern Mediterranean area. Tectonophysics 60, 1-42.

1274

1275

Le Pichon, X. \& Kreemer, C. (2010). The Miocene-to-present kinematic evolution of the 1276 eastern mediterranean and Middle East and its implications for dynamics. Annual Review of 1277 Earth and Planetary Sciences 38, 323-351.

1278

Le Pourhiet, L., Huet, B., May, D. A., Labrousse, L. \& Jolivet, L. (2012). Kinematic 1280 interpretation of the 3D shapes of metamorphic core complexes. Geochemistry Geophysics 1281 Geosystems 13, Q09002.

1282

1283 Lips, A. L. W., Cassard, D., Sözbilir, H., Yilmaz, H. \& Wijbrans, J. R. (2001). Multistage 1284 exhumation of the Menderes Massif, western Anatolia (Turkey). International Journal of 1285 Earth Sciences 89, 781-792. 
1287 Lister, G. S., Banga, G. \& Feenstra, A. (1984). Metamorphic core complexes of Cordilleran type in the Cyclades, Aegean Sea, Greece. Geology 12, 221-225.

1289

Ludwig, K. R. (2001). Isoplot/Ex rev. 2.49 - A Geochronological Toolkit for Microsoft Excel.

Berkeley Geochronology canter. Special publication, No. 1a.

1292

1293

Malinverno, A. \& Ryan, W. B. F. (1986). Extension in the Tyrrhenian Sea and shortening in

1294 the Apennines as result of arc migration driven by sinking of the lithosphere. Tectonics 5, $227-245$.

1296

Martin, L. A. J., Ballèvre, M., Boulvais, P., Halfpenny, A., Vanderhaeghe, O., Duchêne, S. \&

Deloule, E. (2011). Garnet re-equilibration by coupled dissolution-reprecipitation: evidence from textural, major element and oxygen isotope zoning of "cloudy" garnet: Journal of Metamorphic Geology 29, 213-231.

1301

Mehl, C., Jolivet, L. \& Lacombe, O. (2005). From ductile to brittle: Evolution and localization of deformation below a crustal detachment (Tinos, Cyclades, Greece). Tectonics 24, TC4017.

Mehl, C., Jolivet, L., Lacombe, O., Labrousse, L. \& Rimmele, G. (2007). Structural evolution of Andros island (Cyclades, Greece): a key to the behaviour of a flat detachment within an extending continental crust. In: Taymaz, T., Dilek, Y., Ylmaz, Y. (Eds.), The Geodynamics of the Aegean and Anatolia. Geological Society, London, Special Publications 291, 41-73. 
1311 Melinte-Dobrinescu, M. C. et al. (2009). The Messinian Salinity Crisis in the Dardanelles

1312 region: Chronostratigraphic constraints. Palaeogeography, Palaeoclimatology, Palaeoecology $1313278,24-39$.

1314

1315 Menant, A., Jolivet, L., Augier, R. \& Skarpelis, N. (2013). The North Cycladic Detachment

1316 System and associated mineralization, Mykonos, Greece: Insights on the evolution of the

1317 Aegean domain. Tectonics 32, 433-452.

1318

1319 Norton, M. G. (1986). Late Caledonide Extension in western Norway: A response to extreme 1320 crustal thickening. Tectonics 5, 195-204.

1321

1322 Oberhansli, R., Monie, P., Candan, O., Warkus, F. C., Partzsch, J. H. \& Dora, O. O. (1998).

1323 The age of blueschist metamorphism in the Mesozoic cover series of the Menderes Massif.

1324 Schweizerische Mineralogische Und Petrographische Mitteilungen 78, 309-316.

1325

1326 Papanikolaou, D. (1978). Contribution to the geology of Ikaria island, Aegean sea. Annales 1327 Géologiques des Pays Helléniques 29, 1-28.

1328

1329

Paquette, J. L. \& Tiepolo, M. (2007). High resolution $(5 \mu \mathrm{m})$ U-Th-Pb isotope dating of monazite with excimer laser ablation (ELA)-ICP-MS. Chemical Geology 240, 222-237.

1332 Parra, T., Vidal, O. \& Jolivet, L. (2002). Relation between the intensity of deformation and retrogression in blueschist metapelites of Tinos Island (Greece) evidenced by chlorite-mica

1334 local equilibria. Lithos 63, 41-66. 
1336

1337

1338

1339

1340

1341

1342

1343

1344

1345

1346

1347

1348

1349

1350

1351

1352

1353

1354

1355

1356

1357

1358

1359

1360

Pasteris, J. D. \& Wopenka, B. (1991). Raman-Spectra of Graphite as Indicators of Degree of Metamorphism. Canadian Mineralogist 29, 1-9.

Pe-Piper, G. \& Photiades, A. (2006). Geochemical characteristics of the Cretaceous ophiolitic rocks of Ikaria island, Greece. Geological Magazine 143, 417-429.

Photiades, A. D. (2002a). The ophiolitic molasse unit of Ikaria Island (Greece). Turkish Journal of Earth Sciences 11, 27-38.

Photiades, A. D. (2002b). Geological Map of Greece Scale, 1:50000: Island of Ikaria. Institute of Geology and Mineral Exploration.

Platt, J. P., Behr, W. M. \& Cooper, F. J. (2014). Metamorphic core complexes: windows into the mechanics and rheology of the crust. Journal of the Geological Society.

Platt, J. P. \& Vissers, R. L. M. (1989). Extensional collapse of thickened continental lithosphere: A working hypothesis for the Alboran Sea and Gibraltar arc. Geology 17, 540543.

Pourteau, A., Candan, O. \& Oberhänsli, R. (2010). High-pressure metasediments in central Turkey: Constraints on the Neotethyan closure history. Tectonics 29, TC5004.

Pourteau, A., Sudo, M., Candan, O., Lanari, P., Vidal, O. \& Oberhänsli, R. (2013). Neotethys closure history of Anatolia: insights from 40Ar-39Ar geochronology and P-T estimation in high-pressure metasedimentary rocks. Journal of Metamorphic Geology 31, 585-606. 
1362 Rimmelé, G., Jolivet, L., Oberhänsli, R. \& Goffé, B. (2003b). Deformation history of the

1363 high-pressure Lycian Nappes and implications for tectonic evolution of SW Turkey. 1364 Tectonics 22, 1007.

1366 Rimmelé, G., Oberhänsli, R., Goffé, B., Jolivet, L., Candan, O. \& Cetinkaplan, M. (2003a).

1367 First evidence of high-pressure metamorphism in the "Cover Series" of the southern 1368 Menderes Massif. Tectonic and metamorphic implications for the evolution of SW Turkey. 1369 Lithos 71, 19-46.

1371 Ring, U. (2007). The Geology of Ikaria Island: The Messaria extensional shear zone, granites

1372 and the exotic Ikaria nappe. In: Lister, G., Foster, M., Ring, U. (Eds.), Inside the Aegean Core Complexes. Journal of the Virtual Explorer 27.

1374

1375 Ring, U. et al. (2007). Early exhumation of high-pressure rocks in extrusion wedges: Cycladic 1376 blueschist unit in the eastern Aegean, Greece, and Turkey. Tectonics 26, TC2001.

Ring, U. \& Collins, A. S. (2005). U-Pb SIMS dating of synkinematic granites: timing of corecomplex formation in the northern Anatolide belt of western Turkey. Journal of the

1382 Ring, U., Glodny, J., Will, T. M. \& Thomson, S. (2011). Normal faulting on Sifnos and the 1383 South Cycladic Detachment System, Aegean Sea, Greece. Journal of the Geological Society $168,751-768$. 
1386 Ring, U., Glodny, J., Will, T. \& Thomson, S. (2010). The Hellenic Subduction System: High-

1387 Pressure Metamorphism, Exhumation, Normal Faulting, and Large-Scale Extension. In:

1388 Jeanloz, R. \& Freeman, K. H. (eds) Annual Review of Earth and Planetary Sciences. Palo

1389 Alto: Annual Reviews, 45-76.

1390

1391 Ring, U., Laws, S. \& Bernet, M. (1999). Structural analysis of a complex nappe sequence and

1392 late-orogenic basins from the Aegean Island of Samos, Greece. Journal of Structural Geology

$139321,1575-1601$.

1394

1395 Rosenbaum, G., Lister, G. S. \& Duboz, C. (2002). Relative motions of Africa, Iberia and 1396 Europe during Alpine orogeny. Tectonophysics 359, 117-129.

1397

1398 Rosenbaum, G., Ring, U. \& Kühn, A. (2007). Tectonometamorphic evolution of high-

1399 pressure rocks from the island of Amorgos (Central Aegean, Greece). Journal of the 1400 Geological Society, London 164, 425-438.

1401

1402 Royden, L. H. (1993). Evolution of retreating subduction boundaries formed during 1403 continental collision. Tectonics 12, 629-638.

1404

1405 Sanchez-Gomez, M., Avigad, D. \& Heimann, A. (2002). Geochronology of clasts in 1406 allochthonous Miocene sedimentary sequences on Mykonos and Paros Islands: implications 1407 for back-arc extension in the Aegean Sea. Journal of the Geological Society, London 159, 45$1408 \quad 60$. 
1410 Schärer, U. (1984). The effect of initial 230Th disequilibrium on young U-Pb ages: the

1411 Makalu case, Himalaya. Earth and Planetary Science Letters 67, 191-204.

1412

1413 Sengör, A. M. C., Tüysüz, O., İmren, C., Sakınç, M., Eyidoğan, H., Görür, N., Le Pichon, X.

1414 \& Rangin, C. (2005). The North Anatolian Fault: A New Look. Annual Review of Earth and

1415 Planetary Sciences 33, 37-112.

1416

1417 Seydoux-Guillaume, A. M., Paquette, J. L., Wiedenbeck, M., Montel, J. M. \& Heinrich, W.

1418 (2002). Experimental resetting of the U-Th-Pb systems in monazite. Chemical Geology 240, $1419222-237$.

1420

1421 Steck, A. \& Hunziker, J. (1994). The Tertiary structural and thermal evolution of the Central

1422 Alps-compressional and extensional structures in an orogenic belt. Tectonophysics 238, 2291423254.

1424

1425 Sternai, P., Jolivet, L., Menant, A. \& Gerya, T. (2014). Driving the upper plate surface 1426 deformation by slab rollback and mantle flow. Earth and Planetary Science Letters 405, 1101427118.

1429 Stöckhert, B., Brix, M. R., Kleinschrodt, R., Hurford, A. J. \& Wirth, R. (1999).

1430 Thermochronometry and microstructures of quartz-a comparison with experimental flow laws

1431 and predictions on the temperature of the brittle-plastic transition. Journal of Structural 1432 Geology 21, 351-369. 
1434 Thomson, S. N., Ring, U., Brichau, S., Glodny, J. \& Will, T. M. (2009). Timing and nature of

1435 formation of the Ios metamorphic core complex, southern Cyclades, Greece. In: Ring, U.,

1436 Wernicke, B. (Eds.), Extending a Continent: Architecture, Rheology and Heat Budget.

1437 Geological Society, London, Special Publications 321, 139-167.

1438

1439 Tirel, C., Brun, J.-P. \& Burov, E. (2008). Dynamics and structural development of

1440 metamorphic core complexes. Journal of Geophysical Research 113, B04403.

1441

1442 Tomascak, P. B., Krogstad, E. J. \& Walker, R. J. (1996). U-Pb monazite geochronology of 1443 granitic rocks from Maine: Implications for Late Paleozoic tectonics in the northern 1444 Appalachians. The Journal of Geology 104, 185-195.

1445

1446 Trotet, F., Jolivet, L. \& Vidal, O. (2001a). Tectono-metamorphic evolution of Syros and

1447 Sifnos islands (Cyclades, Greece). Tectonophysics 338, 179-206.

1448

1449 Trotet, F., Vidal, O. \& Jolivet, L. (2001b). Exhumation of Syros and Sifnos metamorphic 1450 rocks (Cyclades, Greece). New constraints on the P-T paths. European Journal of Mineralogy $1451 \quad 13,901-920$.

1452

1453 Tschegg, C. \& Grasemann, B. (2009). Deformation and alteration of a granodiorite during

1454 low-angle normal faulting (Serifos, Greece). Lithosphere 1, 139-154.

1455

1456 Urai, J. L., Schuiling, R. D. \& Jansen, J. B. H. (1990). Alpine deformation on Naxos (Greece),

1457 in: Knipe, R. J., Rutter, E. H. (Eds.), Deformation Mechanisms, Rheology and Tectonics.

1458 Geological Society, London, Special Publications 54, 509-522. 
1460 van Achterbergh, E., Ryan, C. G., Jackson, S. E. \& Griffin, W. L. (2001). Data reduction 1461 software for LA-ICP-MS. In: Sylvester, P. (Ed.), Laser ablation-ICP-MS in the Earth Science.

1462 Mineralogical Association of Canada 29, 239-243.

1464 Vandenberg, L. C. \& Lister, G. S. (1996). Structural analysis of basement tectonites from the 1465 Aegean metamorphic core complex of Ios, Cyclades, Greece. Journal of Structural Geology $146618,1437-1454$.

1468 Vanderhaeghe, O. (2004). Structural development of the Naxos migmatite dome. In: Whitney, 1469 D. L., Teyssier, C., Siddoway, C. S. (eds.), Gneiss Domes in Orogeny. Geological Society of 1470 America Special Papers 211-227.

1472 van der Maar, P. A., Feenstra, A., Manders, B. \& Jansen, J. B. H. (1981). The petrology of the 1473 island of Sikinos, Cyclades, Greece, in comparison with that of the adjacent island of Ios. 1474 Neues Jahrbuch für Mineralogie-Abhandlungen 10, 459-469. van Hinsbergen, D. J. J. (2010). A key extensional metamorphic complex reviewed and 1477 restored: The Menderes Massif of western Turkey. Earth-Science Reviews 102, 60-76.

1479 van Hinsbergen, D. J. J., Hafkenscheid, E., Spakman, W., Meulenkamp, J. E. \& Wortel, R. 1480 (2005). Nappe stacking resulting from subduction of oceanic and continetal lithosphere below 1481 Greece. Geology 33, 325-328.

1483 Villa, I. M. (1998). Isotopic closure. Terra Nova 10, 42-47. 
1485 Vitale Brovarone, A., Beyssac, O., Malavieille, J., Molli, G., Beltrando, M. \& Compagnoni, 1486 R. (2013). Stacking and metamorphism of continuous segments of subducted lithosphere in a 1487 high-pressure wedge: The example of Alpine Corsica (France). Earth-Science Reviews 116, $1488 \quad 35-56$.

1489

1490 Weinberg, R. F. \& Hasalová, P. (2015). Water-fluxed melting of the continental crust: A 1491 review. Lithos 212-215, 158-188.

1492

1493 Wernicke, B. (1981). Low-angle normal faults in the Basin and Range Province: nappe 1494 tectonics in an extending orogen. Nature 291, 645-648.

1495

1496 Wernicke, B. (1985). Structural discordance between Neogene detachments and frontal sevier 1497 thrusts, central Mormon Mountain, southern Nevada. Tectonics 4, 213-246.

1499 Whitney, D. L. \& Evans, B. W. (2010). Abbreviations for names of rock-forming minerals. 1500 American Mineralogist 95, 185-187.

1501

1502 Wijbrans, J. R., Schliestedt, M. \& York, D. (1990). Single grain argon laser probe dating of 1503 phengites from the blueschist to greenschist transition on Sifnos (Cyclades, Greece). 1504 Contributions to Mineralogy and Petrology 104, 582-593.

1505

1506 Will, T., Okrusch, M., Schmädicke, E. \& Chen, G. L. (1998). Phase relations in the 1507 greenschist-blueschist-amphibolite-eclogite facies in the system Na2O-CaO-FeO-MgO- 
A12O3-SiO2-H2O (NCFMASH), with application to metamorphic rocks from Samos, Greece.

1509 Contributions to Mineralogy and Petrology 132, 85-102.

1510

1511 Table caption

1512

1513 Table 1: RSCM peak temperature results

1514 RSCM results classified by increasing temperatures. For each sample are indicated the GPS

1515 position, the total number of Raman spectra (n) performed, the mean $\mathrm{R} 2$ ratio and temperature

1516 calculated, both associated with their standard deviation (SD) related to the intra-sample

1517 heterogeneity. Location of samples and $\mathrm{T}_{\max }$ results are given on Fig. 12.

Figure captions

1522 Figure 1: Tectonic map of the Aegean domain

1523 Tectonic map of the Aegean domain showing the main geological units and structures related 1524 to both synorogenic and postorogenic episodes, modified after Jolivet et al. (2013) and 1525 references therein. Original map has been modified incorporating recent works (Ring et al., 1526 1999; Kumerics et al., 2005; Rosenbaum et al., 2007; Huet et al., 2009; Grasemann et al., 1527 2012; Augier et al., 2015). NCDS: North Cycladic Detachment System; WCDS: West 1528 Cycladic Detachment System; NDP: Naxos-Paros Detachment; SCT: South Cycladic Thrust.

1530 Figure 2: Geological map of Ikaria

1531 (a) New geological map of Ikaria proposed in this study. Lithologic outlines correspond to 1532 new field observations and a compilation of existing maps (e.g. Papanikolaou, 1978; 
1533 Photiades, 2002b; Kumerics et al., 2005; Ring, 2007). Also indicated are two representative

1534 tectonometamorphic piles for the eastern and the western parts of Ikaria.

1535

1536 Figure 3: New geological features and precisions about nature of contacts

1537 (a) The intrusive contact between Raches granite and marbles of Ikaria unit is clearly marked

1538 by the presence of granitic dykes within marbles. (b) Southward extension of the Fanari

1539 detachment at Therma, separating conglomerates of Fanari unit and metasediments of Agios-

1540 Kirykos unit. (c) Panorama of the Fanari detachment at Gialiskari between sediments of

1541 Fanari unit and the Raches granite. (d) Close-up view of granite-derived cataclasites beneath

1542 the Fanari detachment at Gialiskari. (e) Details of migmatites from the lower parts of Ikaria

1543 unit preserved in the south of Raches granite. See Fig. 2 for location.

1544

1545 Figure 4: Main planar fabrics

1546 (a) Foliation-map of Ikaria. Geometry of sedimentary bedding in Fanari unit is also showed.

1547 (b) Statistics of the main foliation geometry. Poles of foliation are presented in Schmidt's

1548 lower hemisphere equal-area projection and preferred orientations of foliation is given by the

1549 rose-diagram. The elongation of the cloud allows retrieving the geometry of the dome axis.

1550 Also note that the asymmetry of the cloud calls for the asymmetry of the dome with a steeper

1551 southeast flank. (c) Simplified geological map showing foliation trajectories and traces of the

1552 main shear zones.

1553

1554 Figure 5: Stretching lineation

1555 (a) Stretching lineation-map of Ikaria. Note that the trend of the lineation shows very little 1556 dispersion. It is noteworthy that the strike of the stretching lineation describes slightly curved 1557 patterns from N-S to more NNE-SSW directions. Indicated are the results of the fault-slip data 
1558 inversion. (b) Statistics on the preferred orientation of stretching lineation presented in

1559 Schmidt's lower hemisphere equal-area projection.

1561 Figure 6: Upward strain gradient within Ikaria unit

1562 (a) Incomplete transposition of the compositional layering into a main, flat-lying penetrative

1563 foliation within the deepest parts of the structure. (b) More advanced transposition of the 1564 compositional layering into the flat-lying penetrative foliation. Note that boudin-shaped 1565 volume of rocks preserved isoclinal folds between decameter-scale top-to-the-N shear bands.

1566 (c) Close-up view of the cross-cutting relationships compositional layering and the main 1567 foliation. Note that fold axes are now mostly parallel to the stretching direction. (d) Mylonitic 1568 deformation of the upper parts of Ikaria unit. The foliation dips gently toward the north. 1569 Metabasites form asymmetric pinch-and-swell boudinage indicating top-to-the-N kinematics. (e) Typical mylonites from the uppermost parts of Ikaria unit, near Evdilos. Quartz veins have

1571 been transposed and stretched into the shear direction and forming asymmetric sigmoids

1572 indicating top-to-the-NNE kinematics. (f) Composite cross section showing the first-order 1573 strain gradient and the structural position of outcrops of Fig. 6. Trace is represented on Fig. 2.

1575 Figure 7: Physical conditions of the deformation within Ikaria unit

1576 (a) Small-scale top-to-the-S shear bands operating in the lower parts of Ikaria unit. The 1577 volume of rocks involved in the deformation is quite large and the amphibolite-facies 1578 associations are quite well preserved. Note that in these incipiently deformed rocks, 1579 deformation is rather symmetrical and local top-to-the-S kinematics are sometimes observed. 1580 (b) Close-up view of syn-greenschist-facies mylonites from the core of the Agios-Kirykos 1581 shear zone in the upper parts of Ikaria unit. 
1583

1584

Figure 8: Deformation in Agios-Kirykos unit

Outcrop pictures of rather weak (a) and intense (b) top-to-the-NE asymmetric deformation in Agios-Kirykos unit. Note that shearing, developed in the greenschist-facies conditions, displays a clear evolution to more localized or even cataclastic flow. (c) Large-scale view of the core of the Fanari shear zone at Agios Kiriaki. Exposed are the mylonites of the uppermost parts of Ikaria unit, on the first plane, while sediments of Fanari unit crop out in the background. Close-up views of the deformation of (d) marble and (e) metapelite layers. Marble layers display successive stages of symmetric boudinage, ranging from ductile to strictly brittle while metapelite levels show a strong non-coaxial component consistent with an overall top-to-the-NE kinematics.

Figure 9: The Fanari detachment plane

Large-scale representative view of the Fanari detachment plane at Fanari. The detachment plane is stripped of its sedimentary cover over several hundreds of square meters. Sediments that are almost vertical are preserved in the incised gullies and all along the coast from Fanari to Agios Kirykos. The plane carries series of large-scale corrugations and crescent-shaped structures indicating a consistent top-to-the-NNE kinematics. Note that the detachment plane is cut across by series of high-angle faults carrying sub-horizontal striations. Also are represented stereographic projections of striations and kinematics of both the detachment plane and the faults that offset the plane.

Figure 10: Using microstructures to unfold the Fanari detachment

(a) Sketch depicting the probable geometry of the Fanari detachment prior to its tilting together with the whole system (see Fig. 9). The result is a system where the detachment plane operates at shallow angle with dextral-normal-sense. In the restored position, sediments 
1608 appear pervasively affected by a single set of conjugate normal faults. (b) Outcrop pictures

1609 and stereographic projections of fault systems before and after back-tilting rotation for sites 6

1610 and 7 (see Fig. 5 for location). In this restored position, paleostress solutions are all consistent

1611 with a unique and common NNE-SSW to NE-SW extensional stretching. This orientation is

1612 consistent with the paleostress field deduced from other stations throughout the island (see

1613 Fig. 11). Note that, conversely, three successive stress states are required to account for the

1614 heterogeneous fault populations present in their current position.

1615

1616 Figure 11: Small-scale brittle structures

1617 Detailed results of the fault-slip data inversion. Fault planes, associated striae and results of

1618 inversion were plotted using WinTensor software in Schmidt's lower hemisphere equal-area

1619 projection (Delvaux and Sperner, 2003). Also is presented a representative outcrop recognized

1620 as demonstrative of a brittle stage subsequently developed after the ductile one (site 1; see

1621 location on Fig. 5). Faults occur as a dense array of rather steep normal faults. Note the

1622 consistency of the NNE-SSW to NE-SW direction of extension all over the island.

1623

1624 Figure 12: RSCM peak temperature results

1625 (a) Sampling map used for the RSCM study. In the bottom right corner, $\mathrm{T}_{\max }$ are sorted by

1626 increasing temperature, where errors brackets correspond to intra-sample heterogeneity

1627 standard deviation. Note that temperature is comparable for two samples, positioned side by

1628 side in the chart, for Ikaria unit on one hand, and for Agios Kirykos unit on the other hand.

1629 But the two units are characterized by clearly differentiable bulk temperature. (b) $\mathrm{T}_{\max } \mathrm{vs}$ 1630 structural position for the northeastern part (samples used for (b) are written in bold on the 1631 map). Note the gap of temperature near the Agios-Kirykos shear zone, quite clear on the

1632 Therma cross section. (c) Increasing temperature approaching the Raches granite. 
1634 Figure 13: U-Th- $\mathrm{Pb}$ analyses on monazite from migmatite sample IK01A

1635 (a) Typical textural relationships between monazite (Mnz) crystals and the magmatic 1636 paragenesis as explored by BSE mean. Mnz 3 is included into biotite (Bt). (b) Details of the 1637 internal texture of Mnz 3 and Mnz 4 monazite crystals. BSE image reveal a clear core-rim 1638 textures. Is also shown the location of ICPMS laser ablation analysis $(9 \mu \mathrm{m})$ and their 1639 corresponding ${ }^{208} \mathrm{~Pb} /{ }^{232} \mathrm{Th}$ ages $(2 \sigma$ level). Note the correlation between ages and the core-rim 1640 textures. (c) ${ }^{206} \mathrm{~Pb} /{ }^{238} \mathrm{U}$ vs ${ }^{208} \mathrm{~Pb} /{ }^{232} \mathrm{Th}$ diagram for all data showing a ${ }^{208} \mathrm{~Pb} /{ }^{232} \mathrm{Th}$ age of $15.7 \pm$

$16410.2 \mathrm{Ma}$ concordant with the ${ }^{206} \mathrm{~Pb} /{ }^{238} \mathrm{U}$ ages. (d) Tera-Wasserburg diagram for all analyses, 1642 intercepting the Concordia at $15.1 \pm 0.2 \mathrm{Ma}$. Discordant $\mathrm{U} / \mathrm{Pb}$ ages suggest a slight common

$1643 \mathrm{~Pb}$ contamination and the uncertainty of the ${ }^{207} \mathrm{~Pb} /{ }^{235} \mathrm{U}$ ages due to the low ${ }^{207} \mathrm{~Pb}$ content of 1644 young monazites. In this study, only the ${ }^{208} \mathrm{~Pb} /{ }^{232} \mathrm{Th}$ ages were considered (inset c).

1645 Mineral abbreviations are after Whitney and Evans (2010)

1646

1647 Figure 14: Large-scale structure and available time-constraints

1648 (a) Three-dimensions large-scale sketch of Ikaria depicting the relationships between the 1649 structural dome, the synkinematic intrusions and the major shear zones. (b) Time-chart 1650 compiling all geochronological constraints available for Ikaria. Note that both the 1651 metamorphic dome and the late intrusions share a common fast cooling from 11-10 Ma 1652 onward. U/Pb ages on zircon (Zrn) are from Bolhar et al. (2010); K/Ar ages on muscovite 1653 (Ms) and biotite (Bt), Rb/Sr ages on muscovite and FT ages on apatite (Ap) are from Altherr 1654 et al. (1982) and Kumerics et al. (2005). (U-Th)/He ages on apatite and FT ages on zircon are 1655 from Kumerics et al. (2005); K/Ar ages on hornblende (Hbl) are from Altherr et al. (1982). 1656 Mean closure temperature are from Harrison (1981), Steck and Hunziker (1994), Grove and 1657 Harrison (1996), Brandon et al. (1998), Ketcham et al. (1999), Farley (2000), Cherniak and 
1658 Watson (2001) and Harrison et al. (2009). K/Ar, Ar/Ar and Rb/Sr ages on metamorphic rocks

1659 could reflect deformation-assisted crystallization (Kumerics et al., 2005) or cooling (Altherr et

1660 al., 1982). Same ages on granites are interpreted as cooling ages (Altherr et al., 1982;

1661 Kumerics et al., 2005). The new age of partial melting from this study is also showed.

1662 Question mark is associated with ages which are discussed in the text.

1663

1664 Figure 15: Large-scale implications

1665 (a) Tectonic map of synorogenic and postorogenic structures in the Aegean domain showing

1666 i) how far the back-arc postorogenic extension remains highly asymmetric in the center of the 1667 domain and ii) the footprint of the central Aegean HT zone where MCCs are described. Red 1668 and green arrows indicate the ductile sense of shear associated to the Oligo-Miocene 1669 extensional episode associated with the NCDS, the WCDS and the NDP (Lister et al., 1984; 1670 Faure et al., 1991; Gautier and Brun, 1994; Vandenberg and Lister, 1996; Jolivet and Patriat, 1671 1999; Mehl et al., 2005; 2007; Huet et al., 2009; Grasemann et al., 2012; Augier et al, 2015).

1672 On Syros and Sifnos islands, the synorogenic top-to-the-ENE sense of shear is associated to

1673 the synorogenic Vari detachment of Syros (Trotet et al., 2001a; 2001b). (b) Stretching-parallel

1674 cross-section through the central Aegean HT zone where intensity of stretching and 1675 asymmetry of the deformation are maximum. 
Click here to download high resolution image
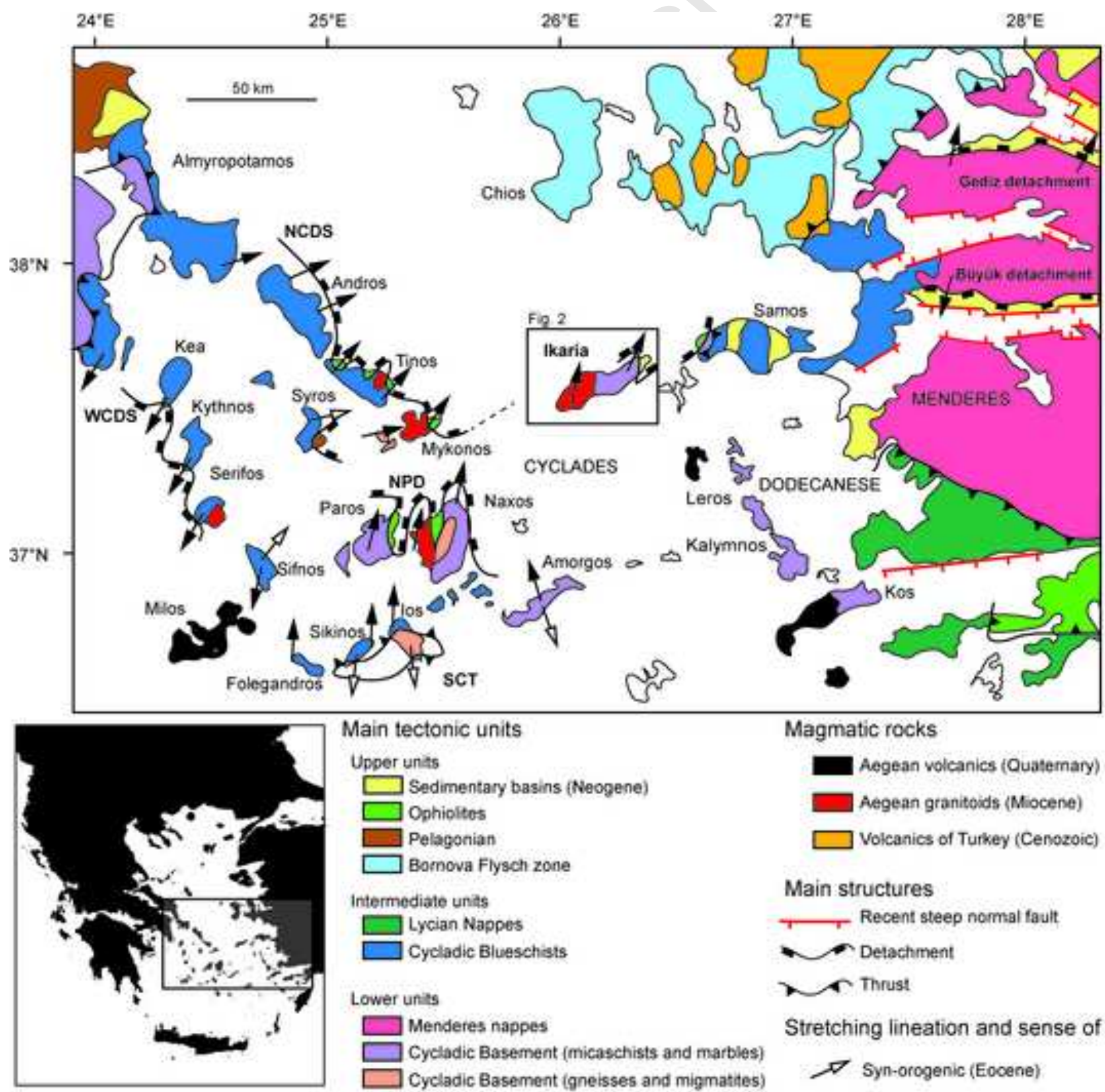

Main tectonic units

Upper units

$\square$ Sedimentary basins (Neogene)

$\square$ Ophiolitos

Pelagonian

$\square$ Bomova Flysch zone

Intermediate units

$\square$ Lycian Nappes

Cycladic Blueschists

Magmatic rocks

Lower units

$\square$ Menderes nappes

Cycladic Basement (micaschists and marbles)

Cycladic Basement (gneisses and migmattes)

Aegean volcanics (Quatemary)

$\square$ Aegean granitoids (Miocene)

$\square$ Volcanics of Turkey (Cenozoic)

Main structures

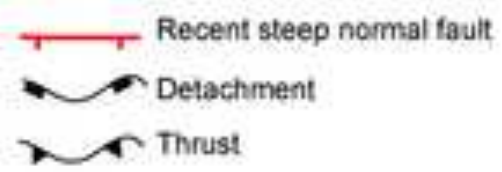

Stretching lineation and sense of shear

$\neg$ Syn-orogenic (Eocene)

- Post-orogenic (Oligo-Miocene) rage $/ U$ or 86 
Click here to download high resolution image

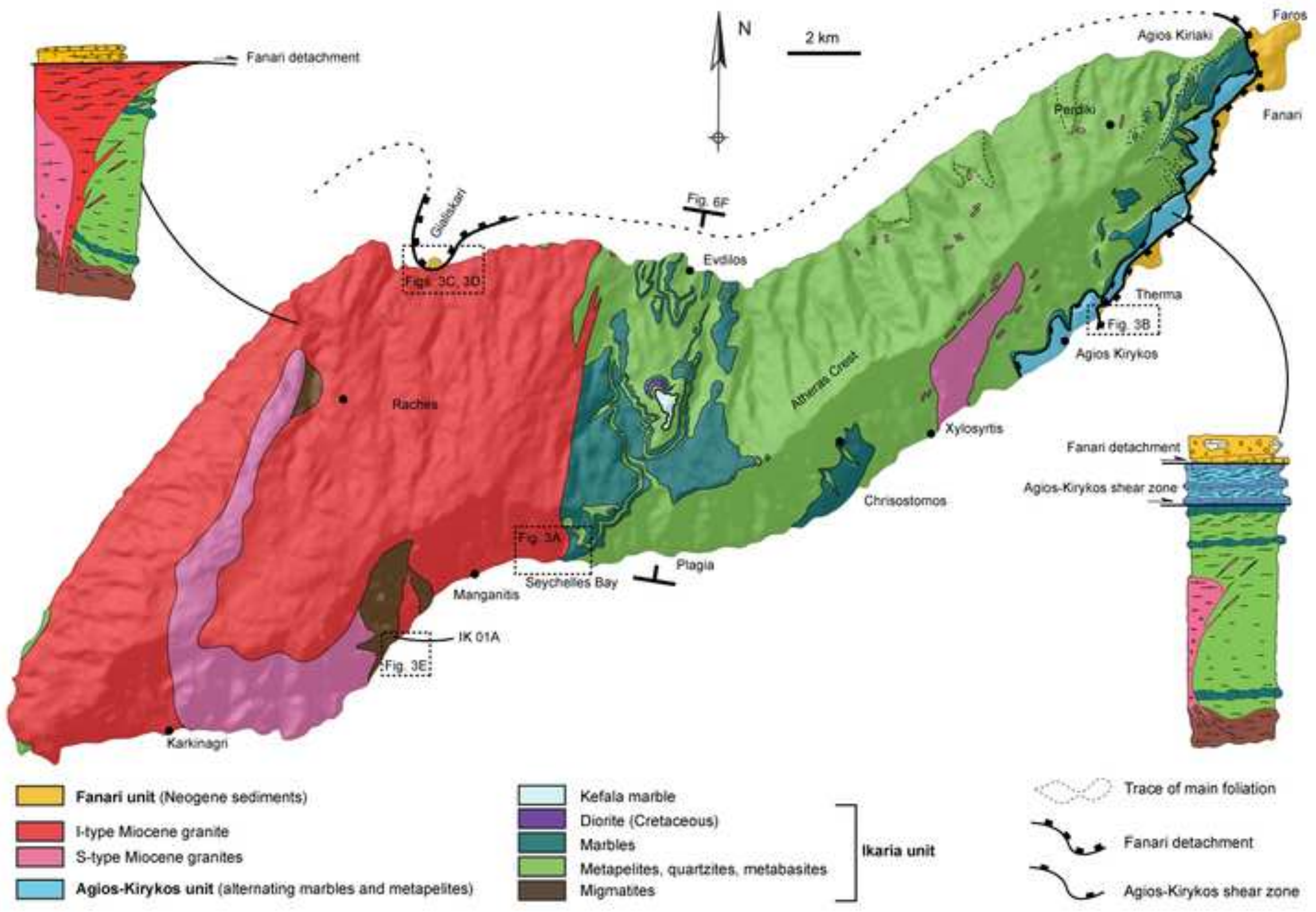

Page 71 of 86 
Figure

АCCEPTED MANUSCRIPT

Click here to download high resolution image

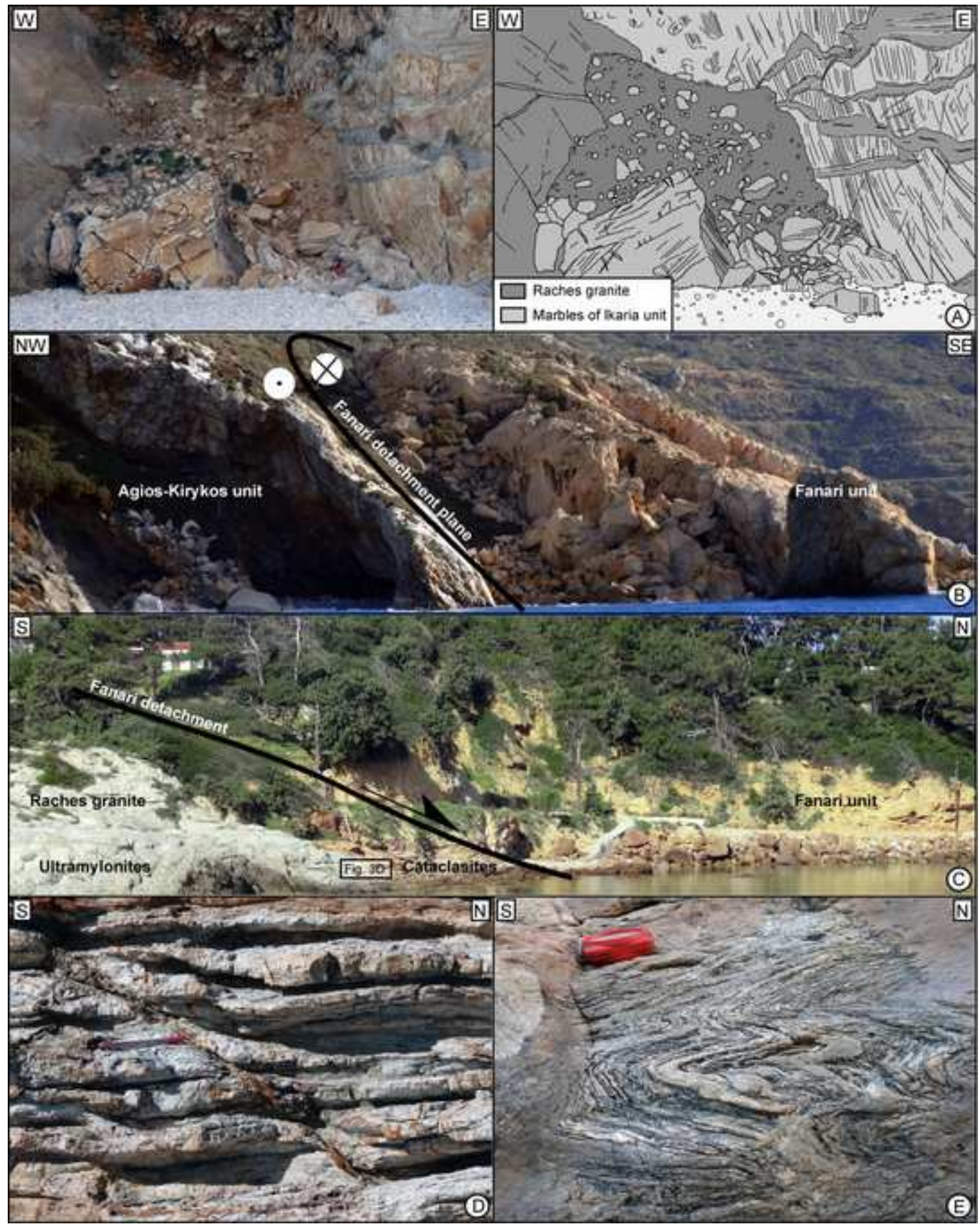


Click here to download high resolution image

Main planar fabrics

Foliation

y This study

Y Compitation from Laurent et al. (2015) and Photiades (20020)

Bedding in Fanari unit

$\checkmark$ This study
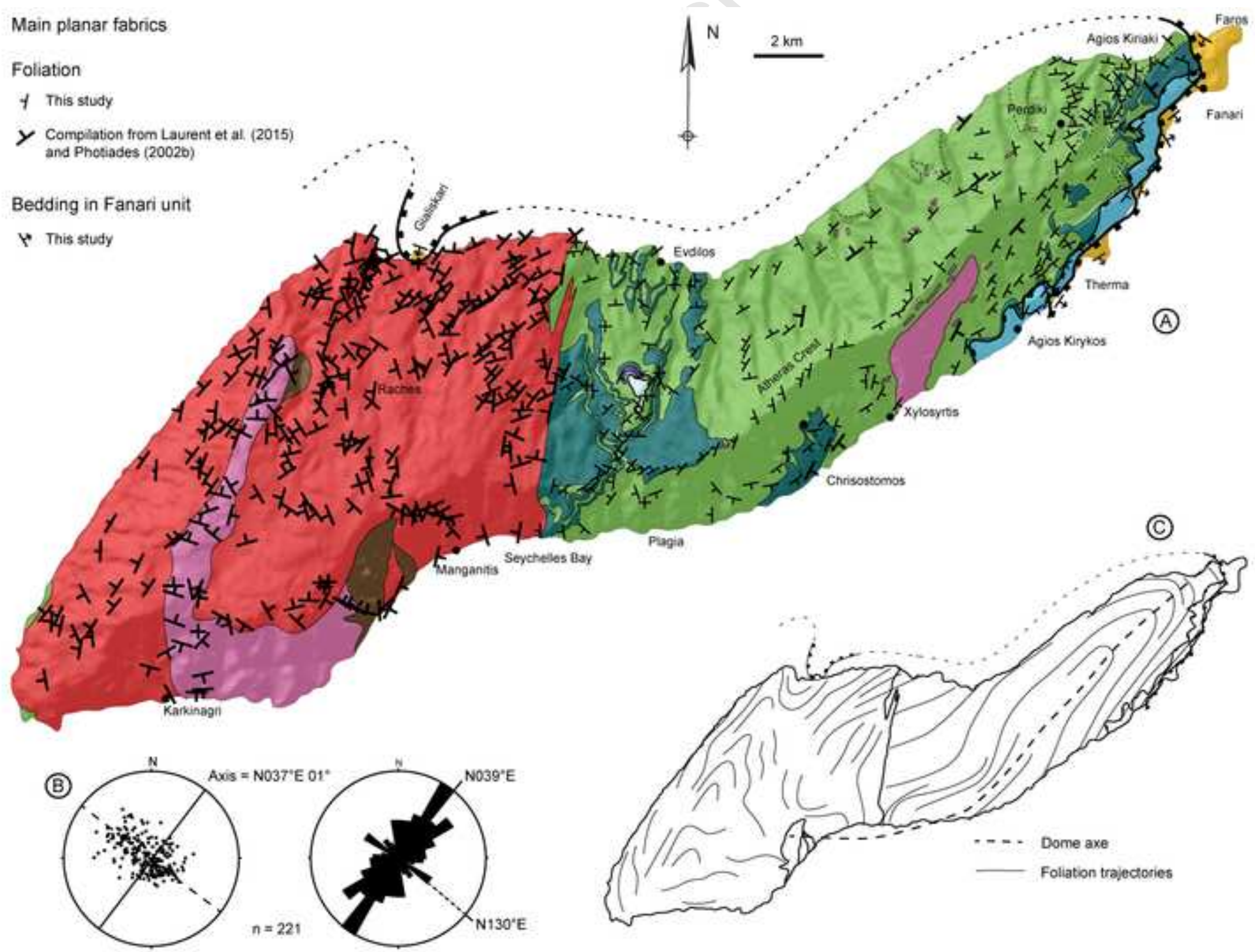

()

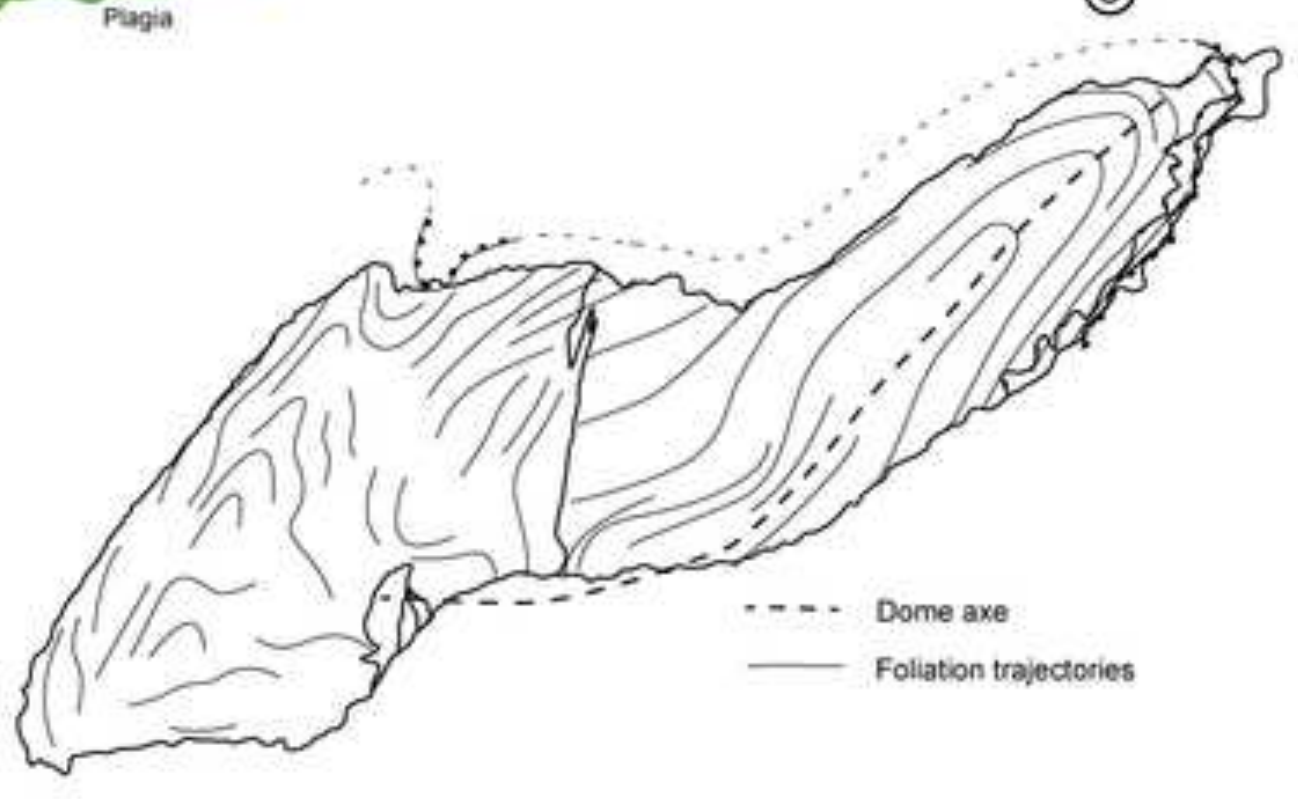




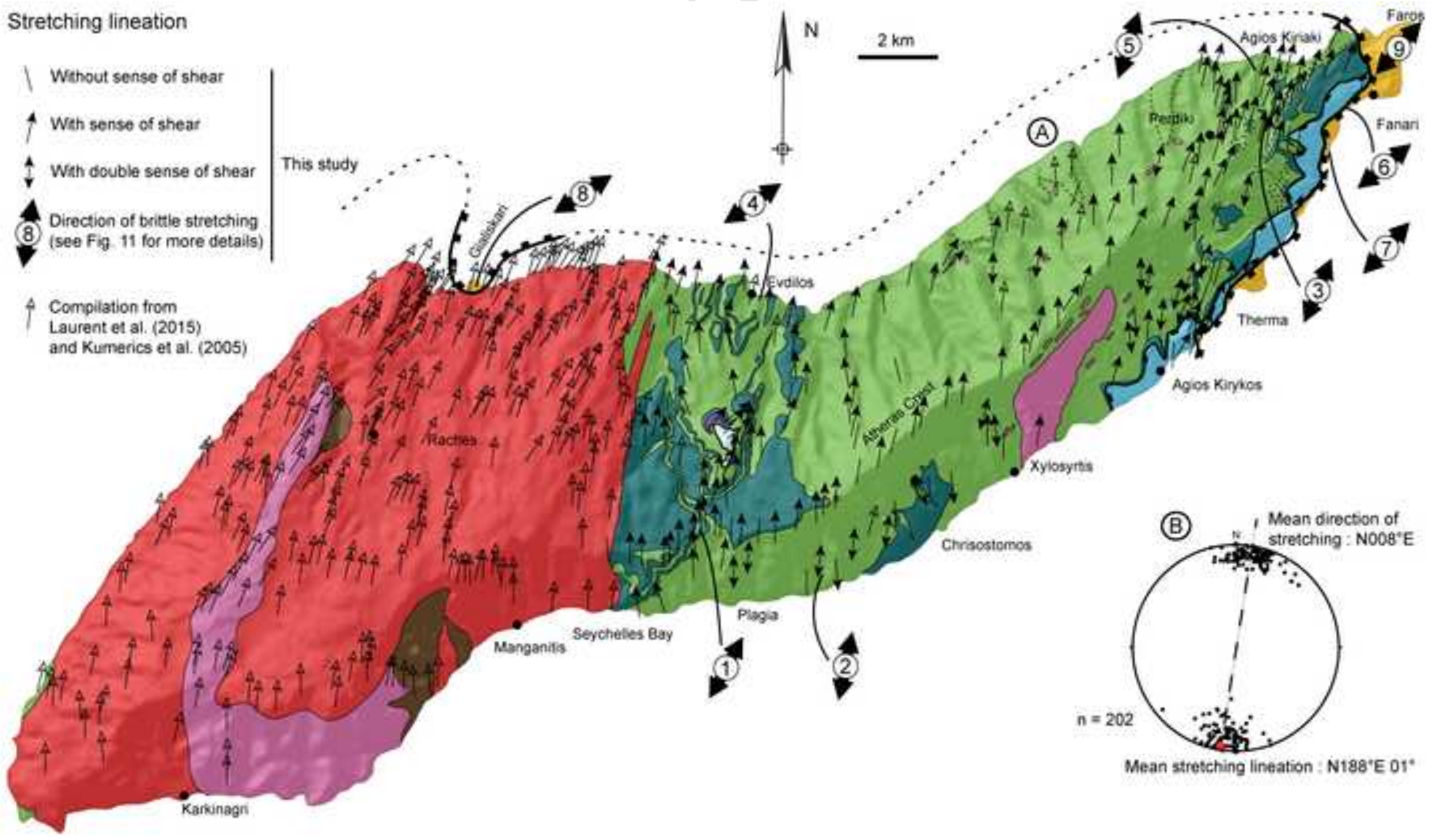




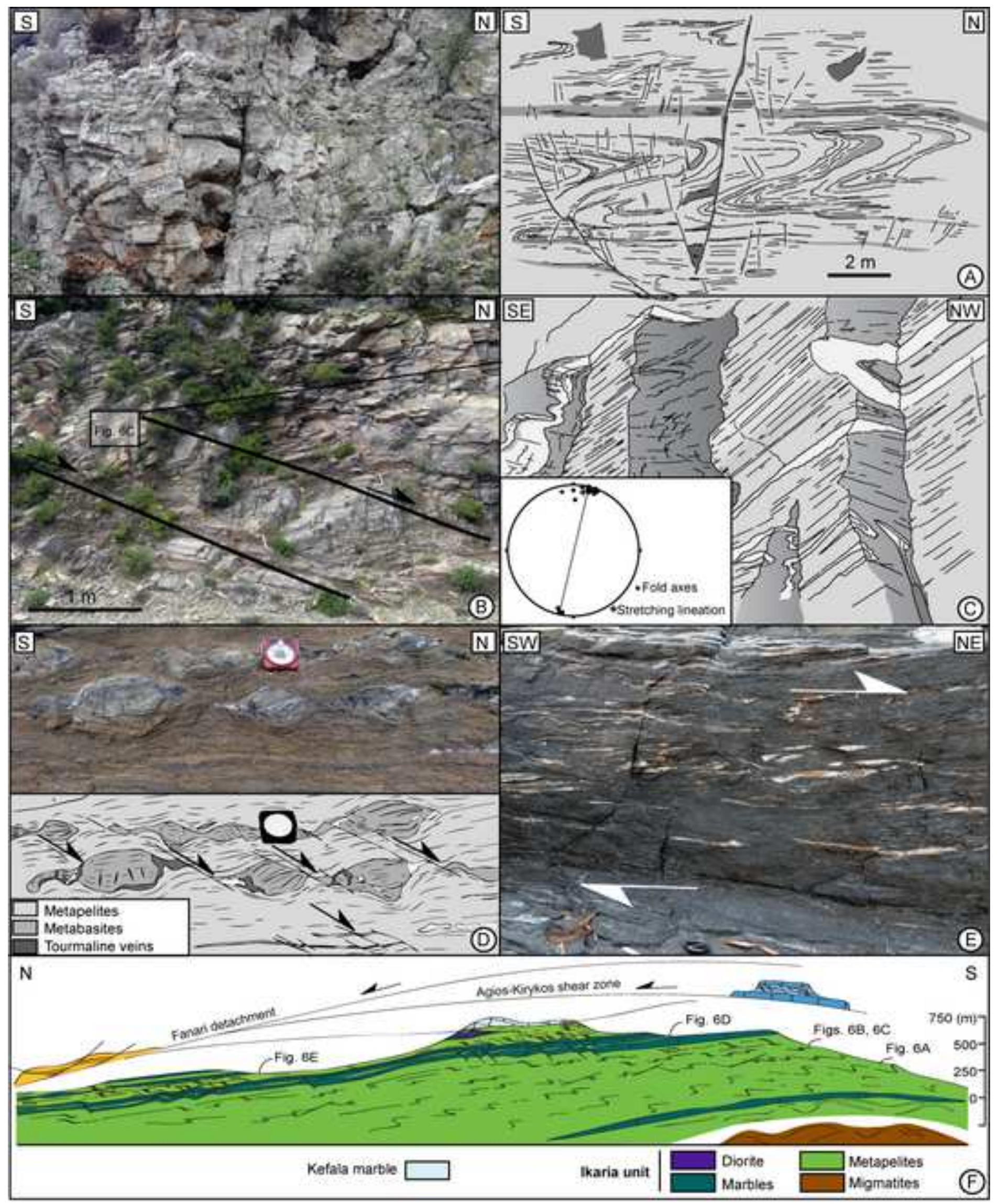


Click here to download high resolution image
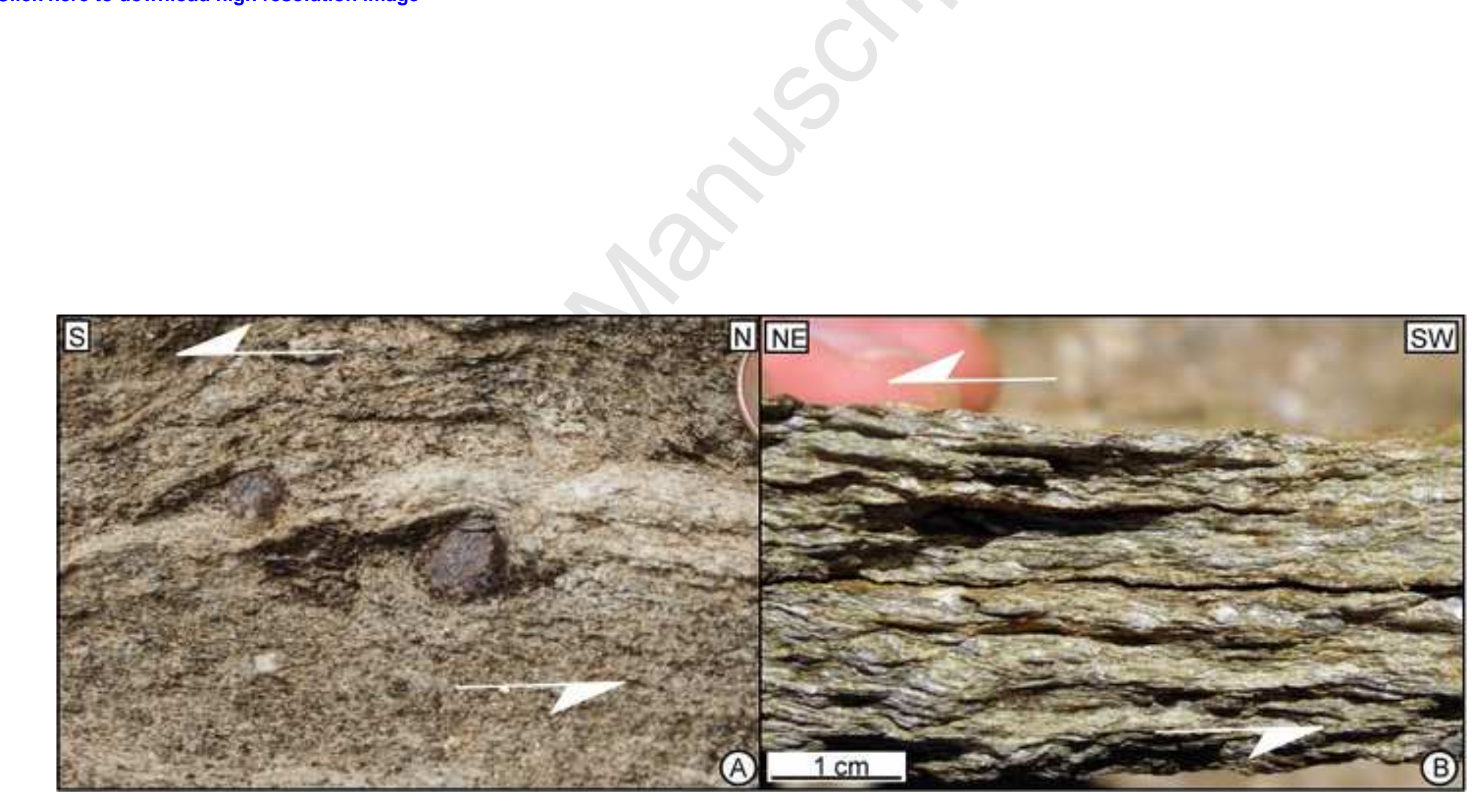 \\ Page 76 of 86}

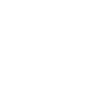

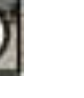

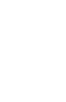

更
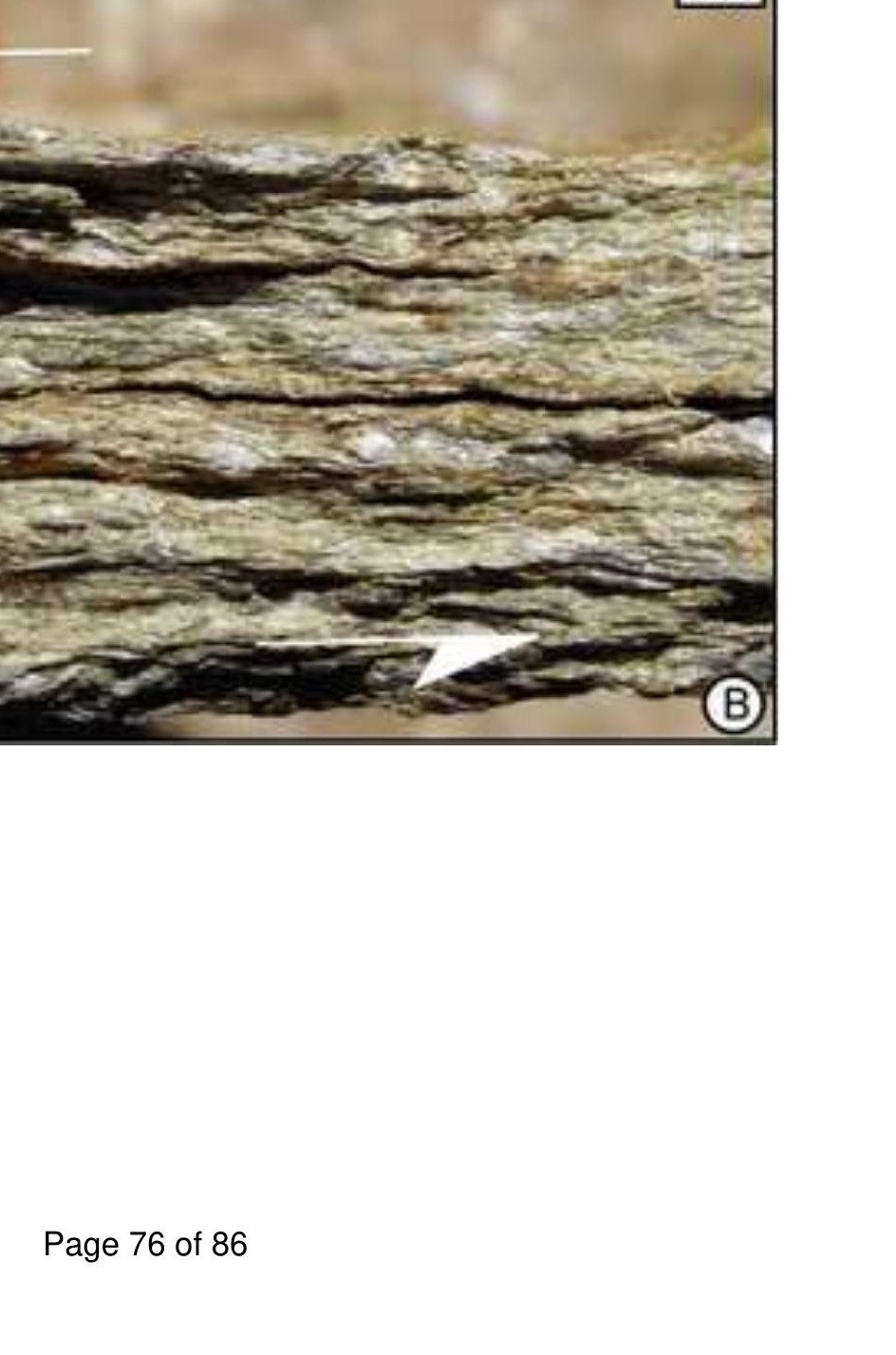


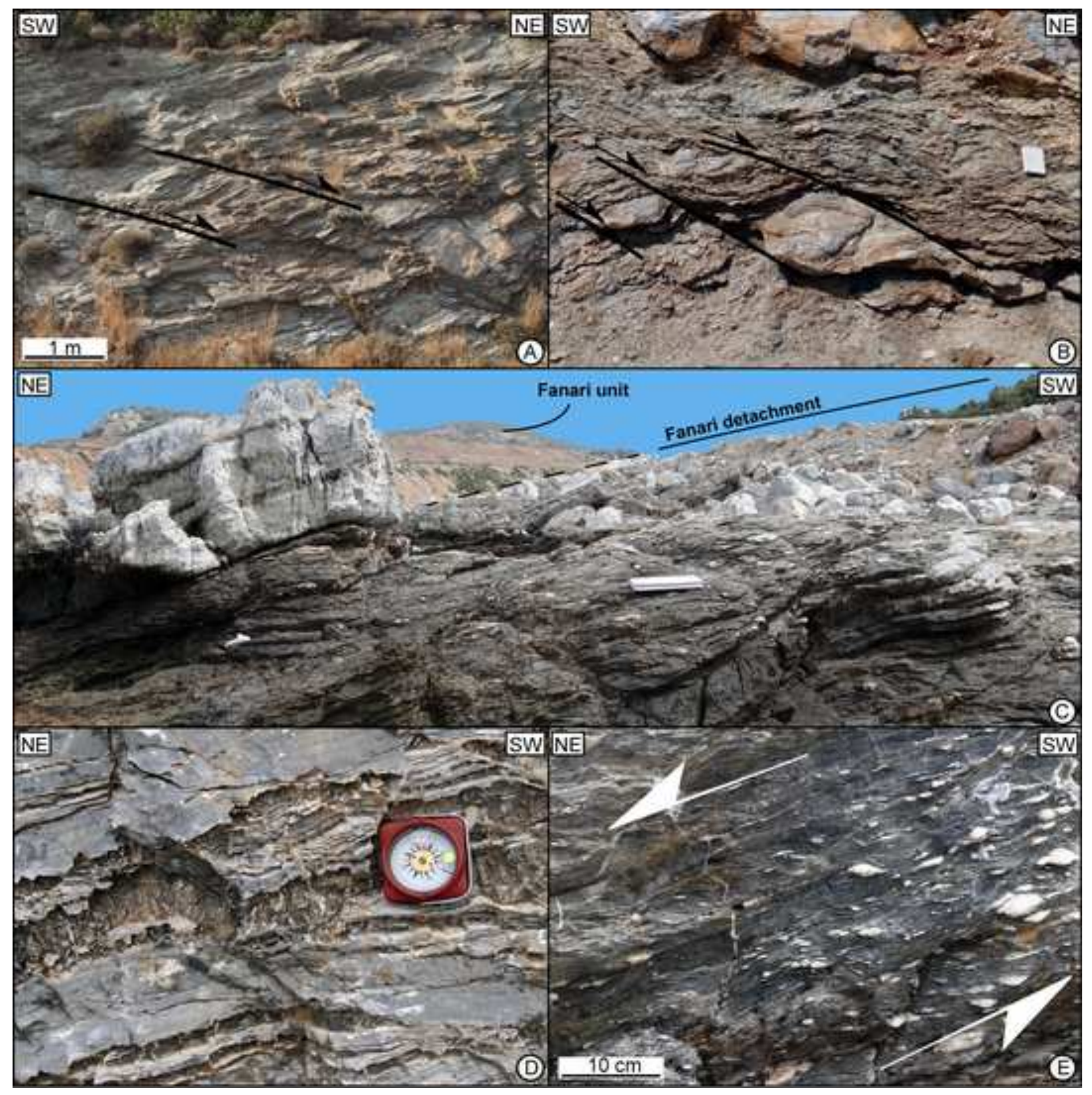




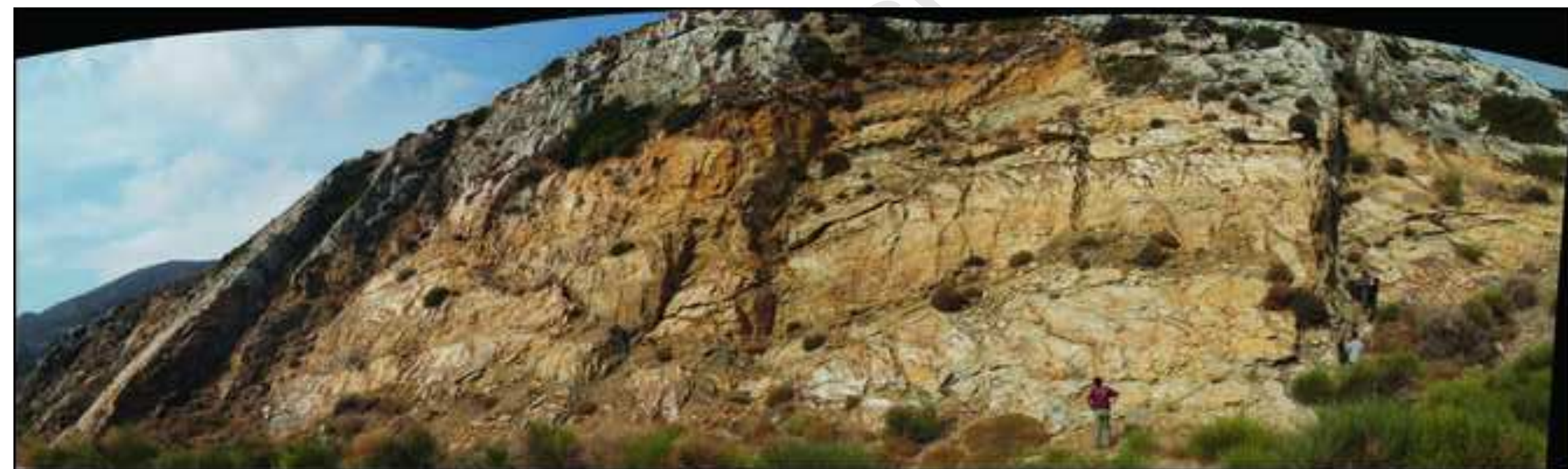

\section{SW}

NII)

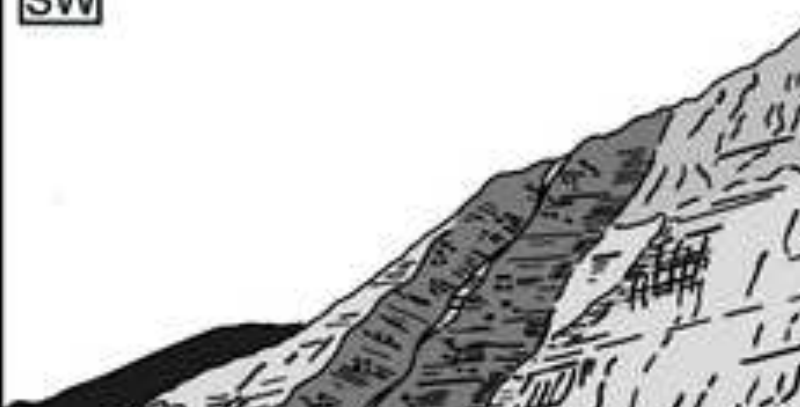

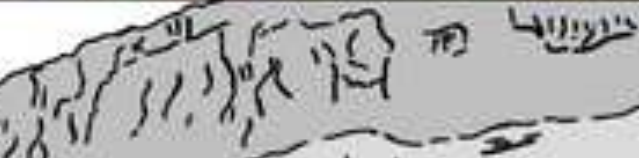

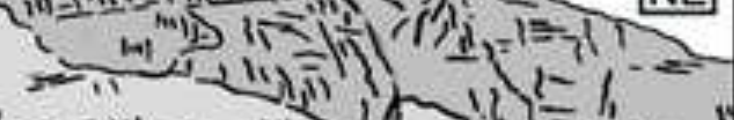
(4) - , ,<smiles>C=IC=[I-]</smiles>
(1:: (n) $-7,11212=$ in.

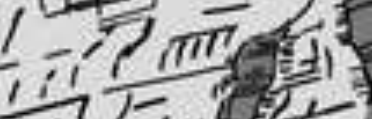

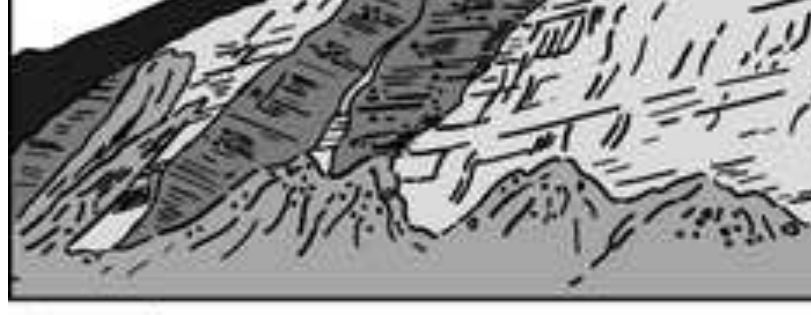

$\square$ Detachment plane

Fault planes offsetting the detachment

Sediments of Fanari unit
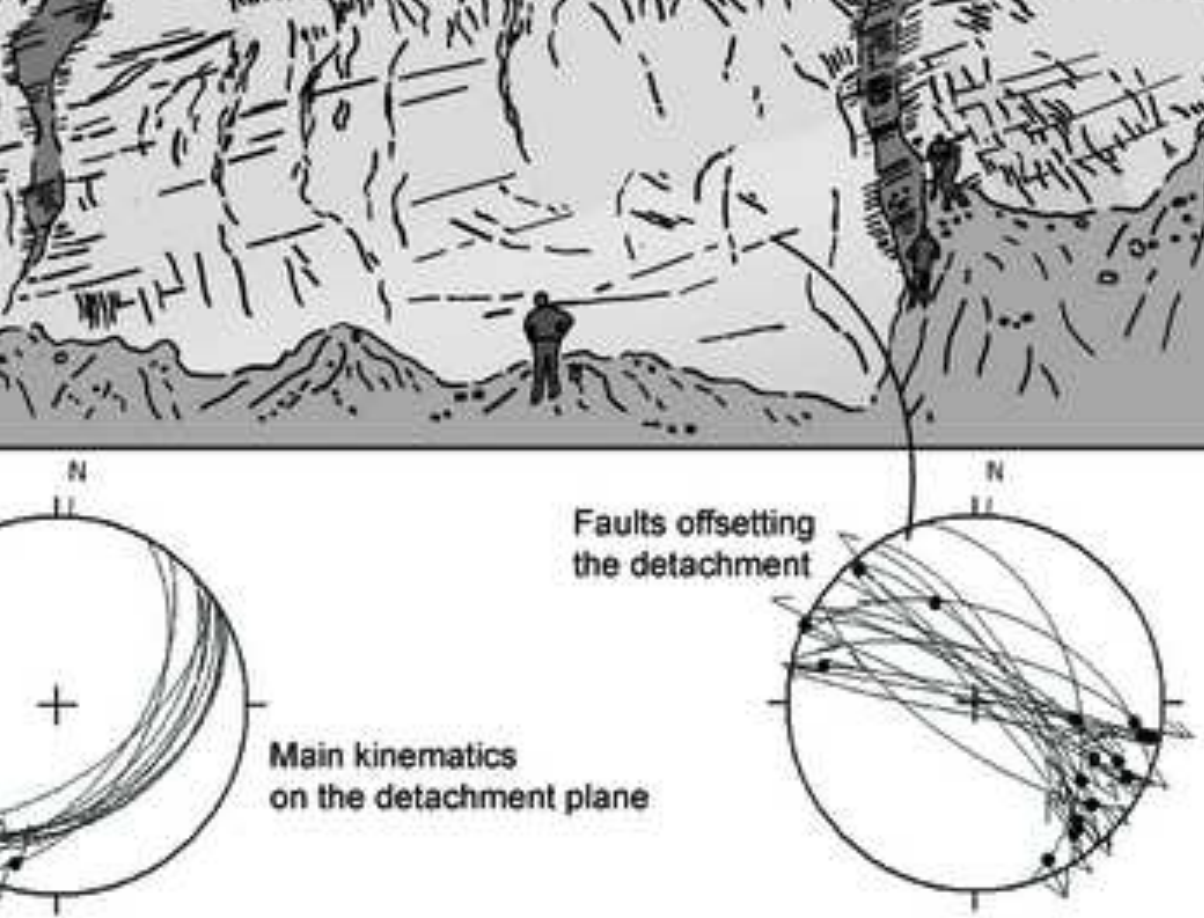

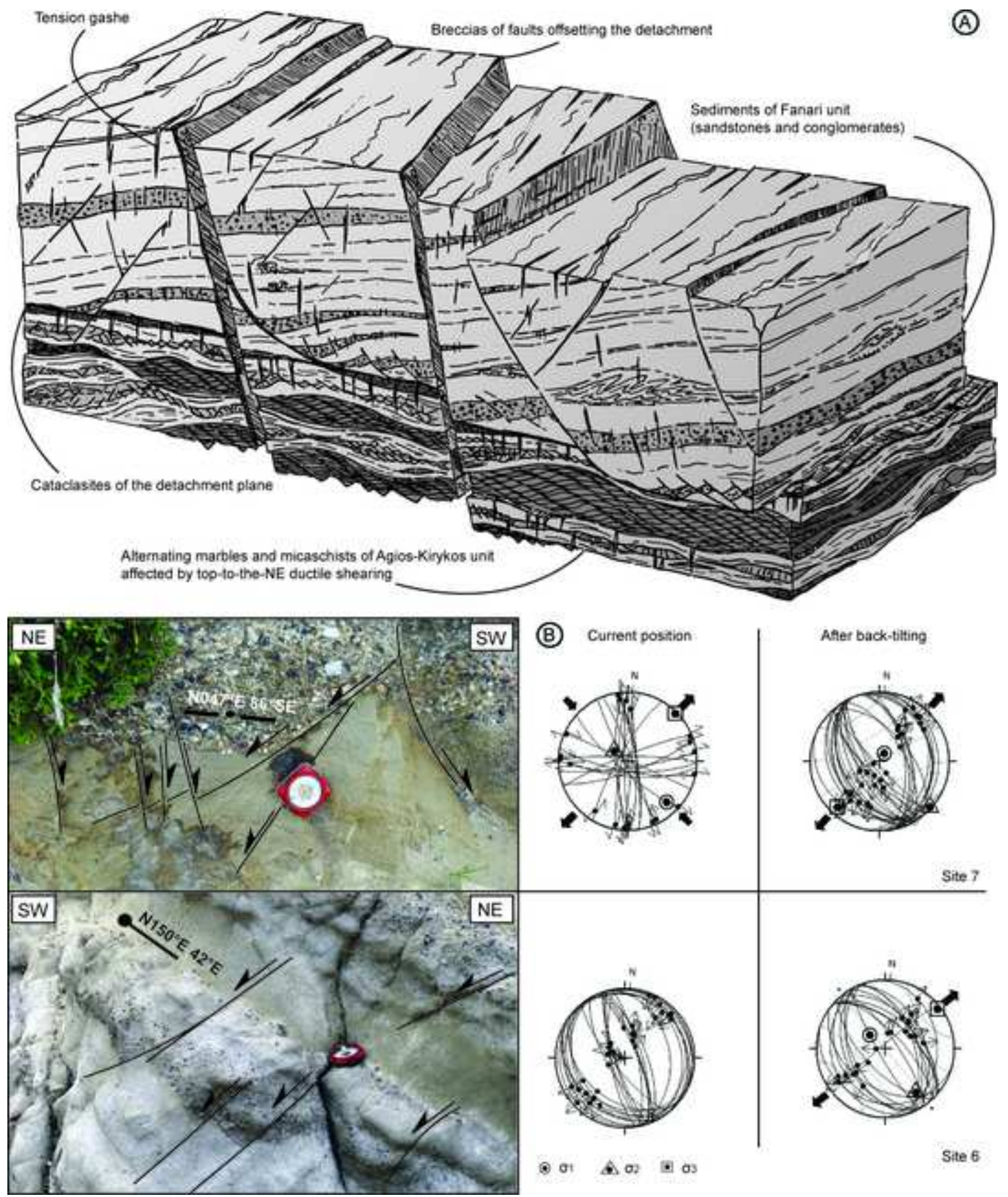

(B) Current postion

Ather back-tilting
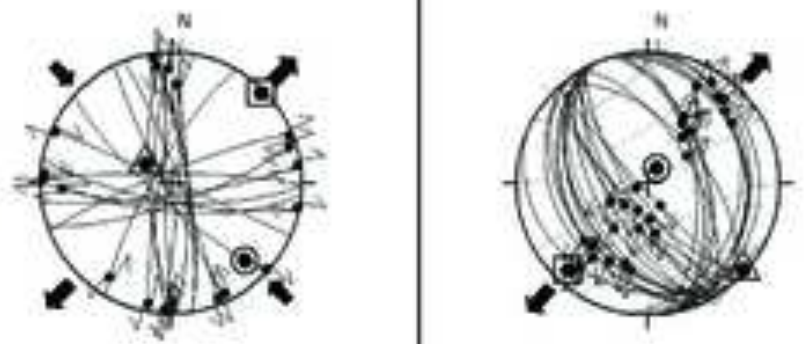

Site 7
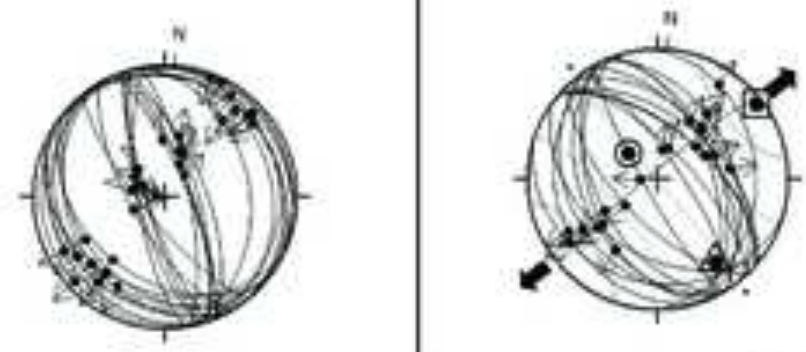

(9) \& क 403 


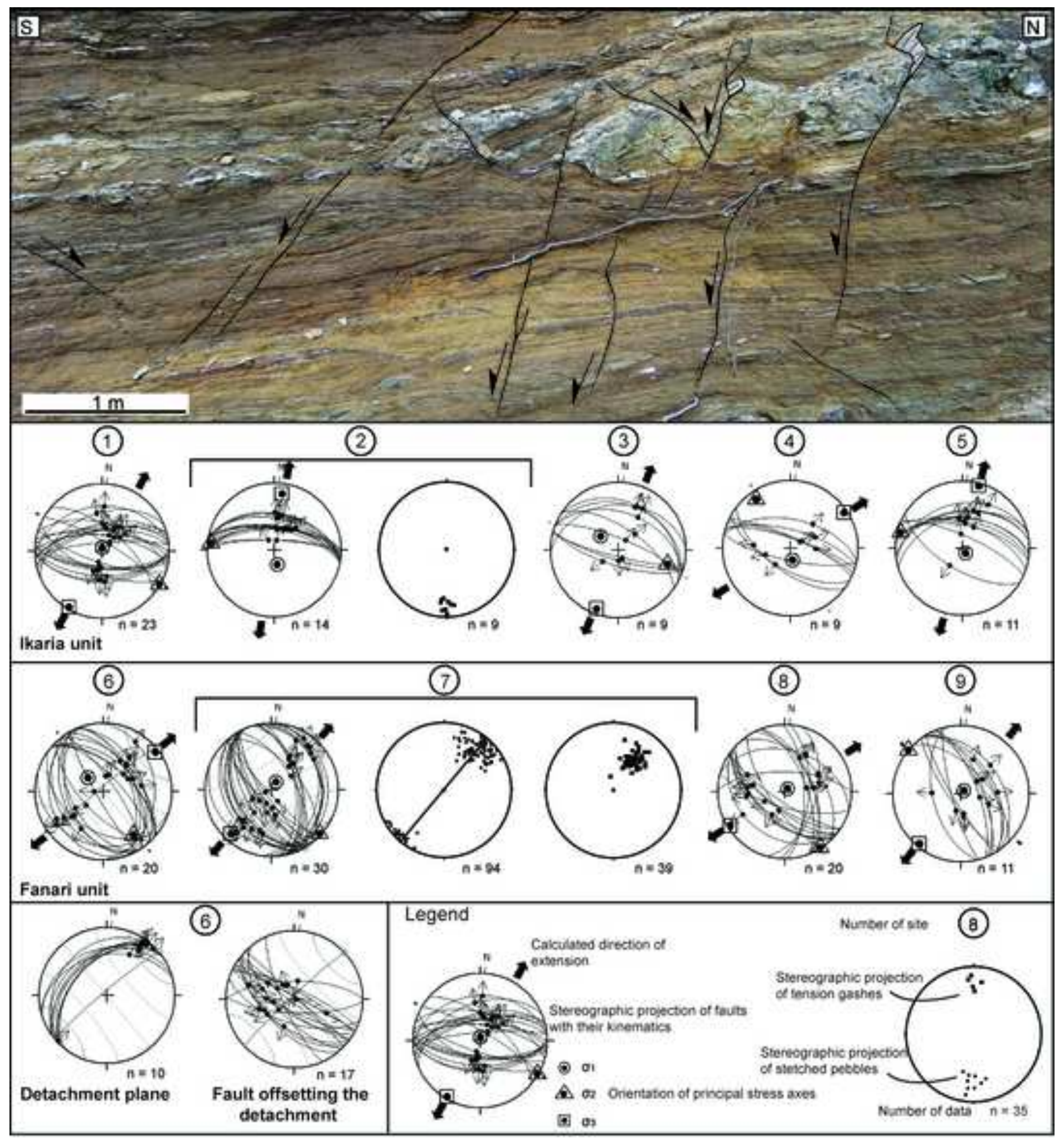




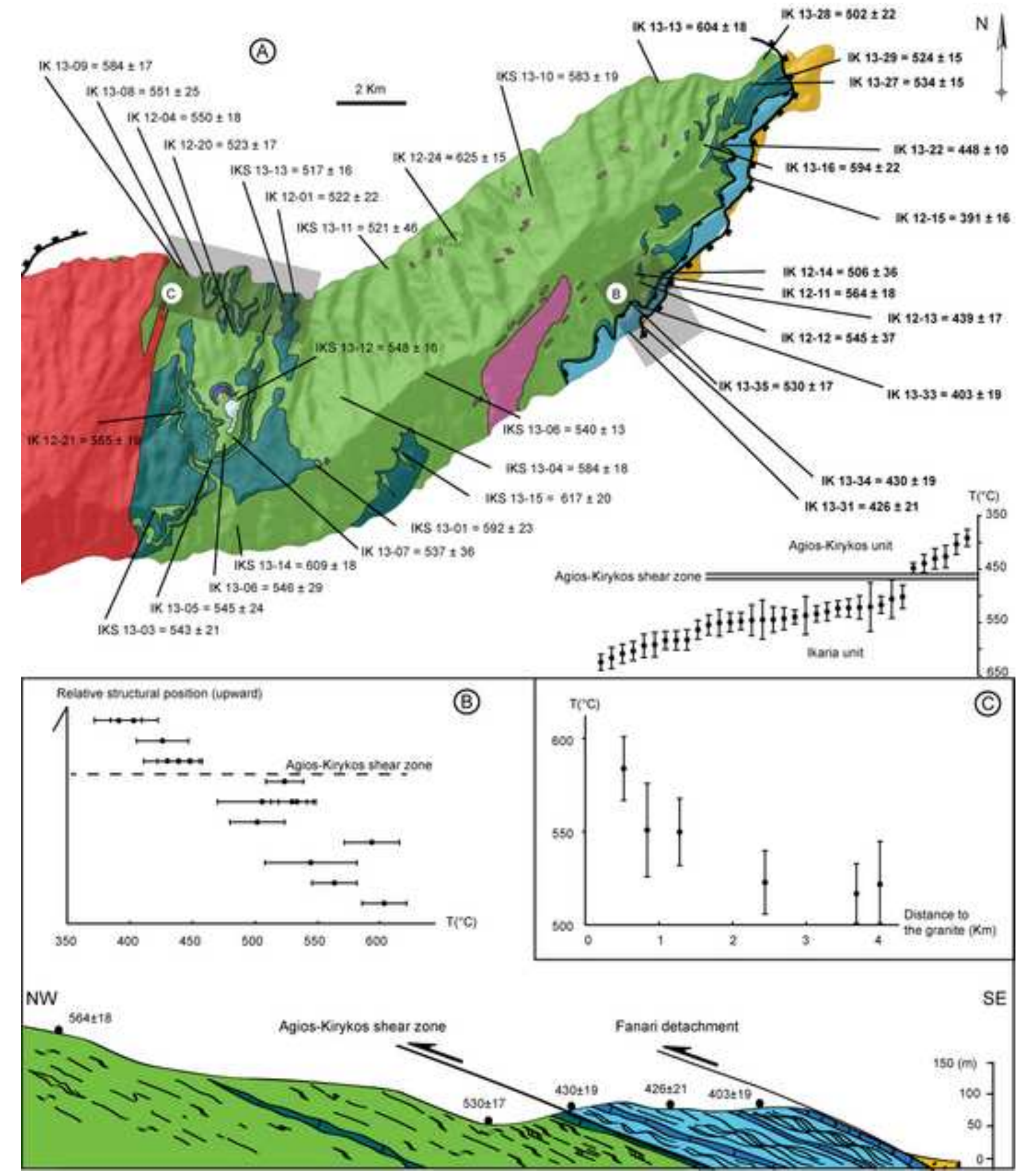


Click here to download high resolution image
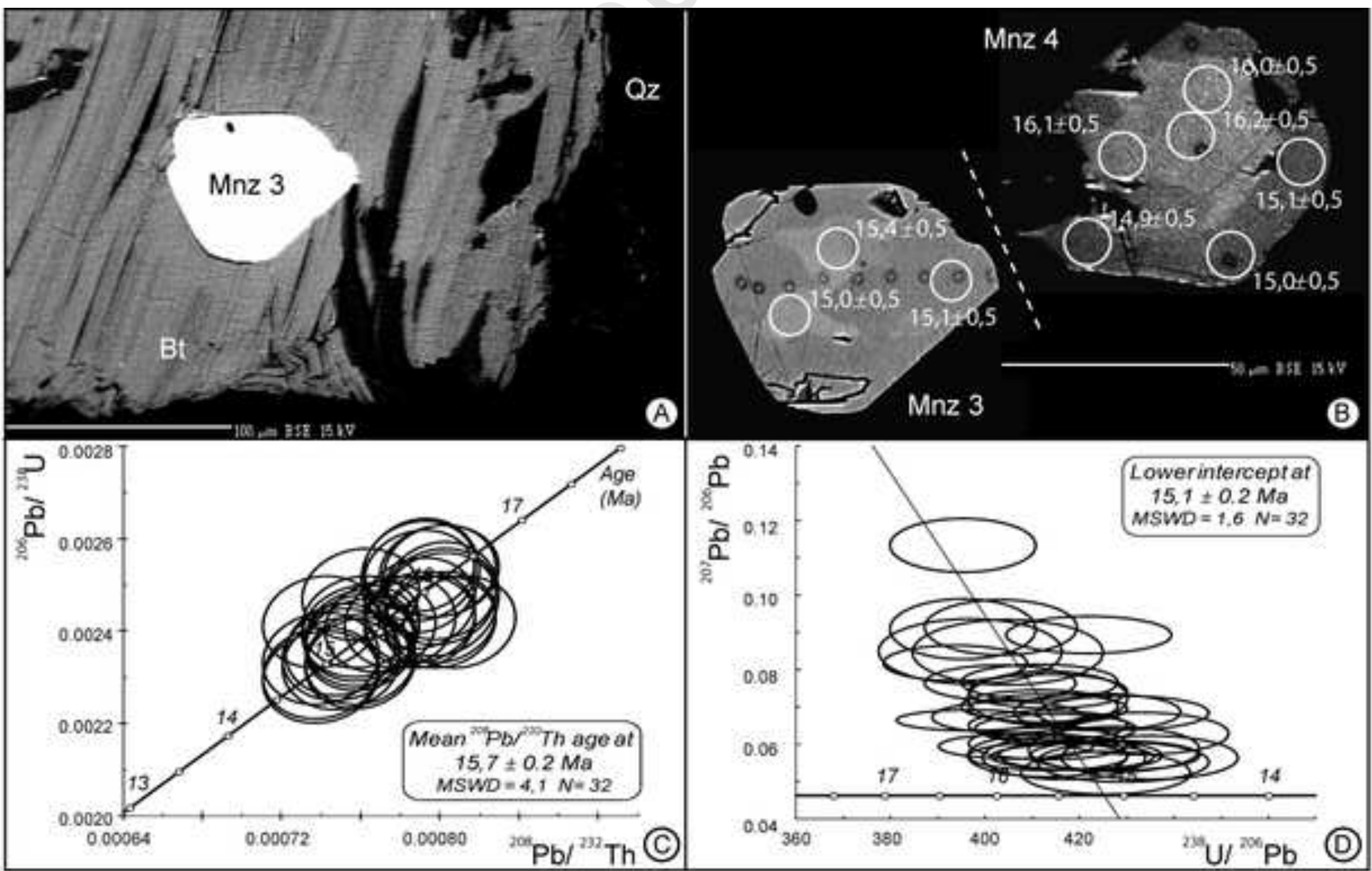


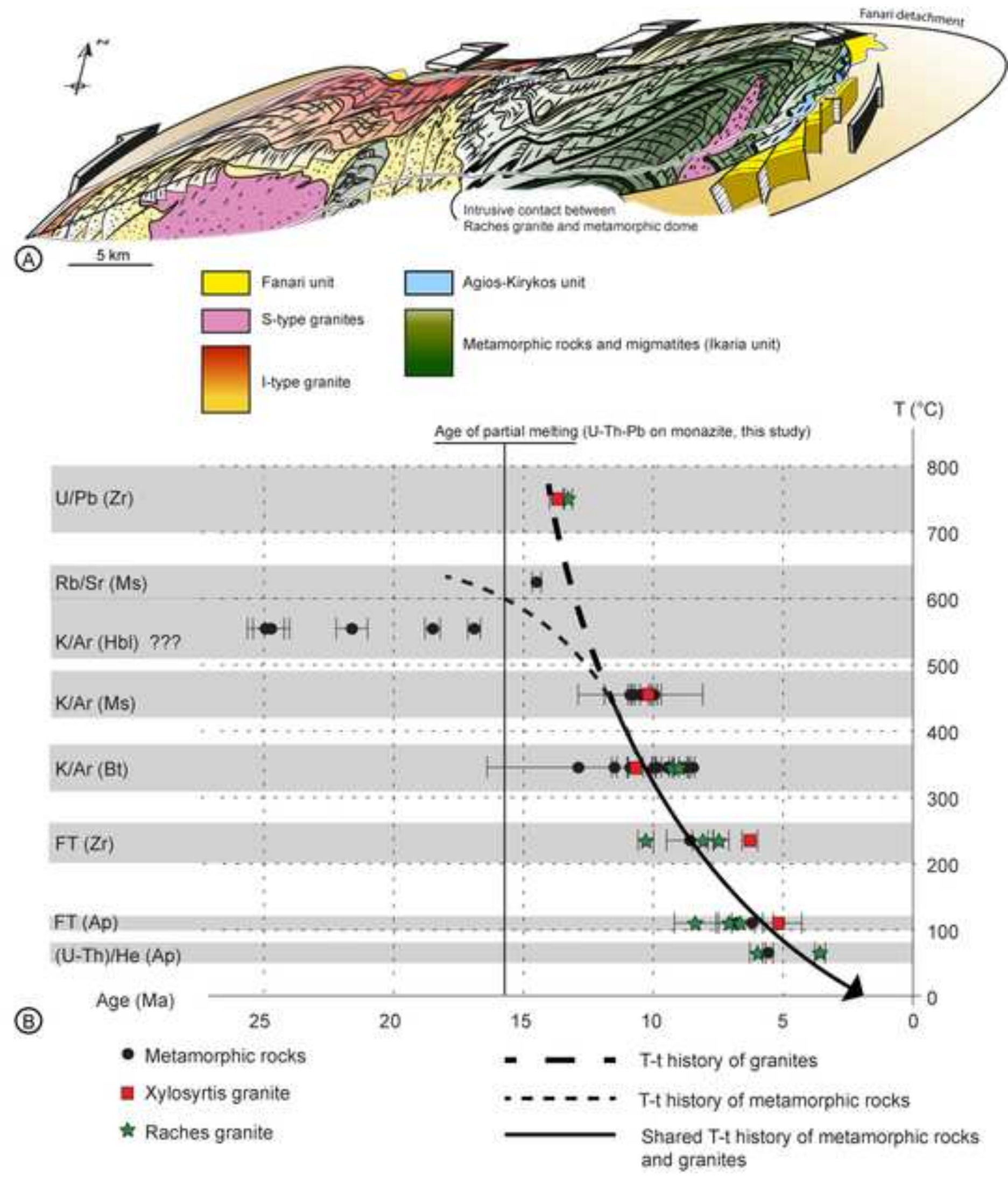


Click here to download high resolution image

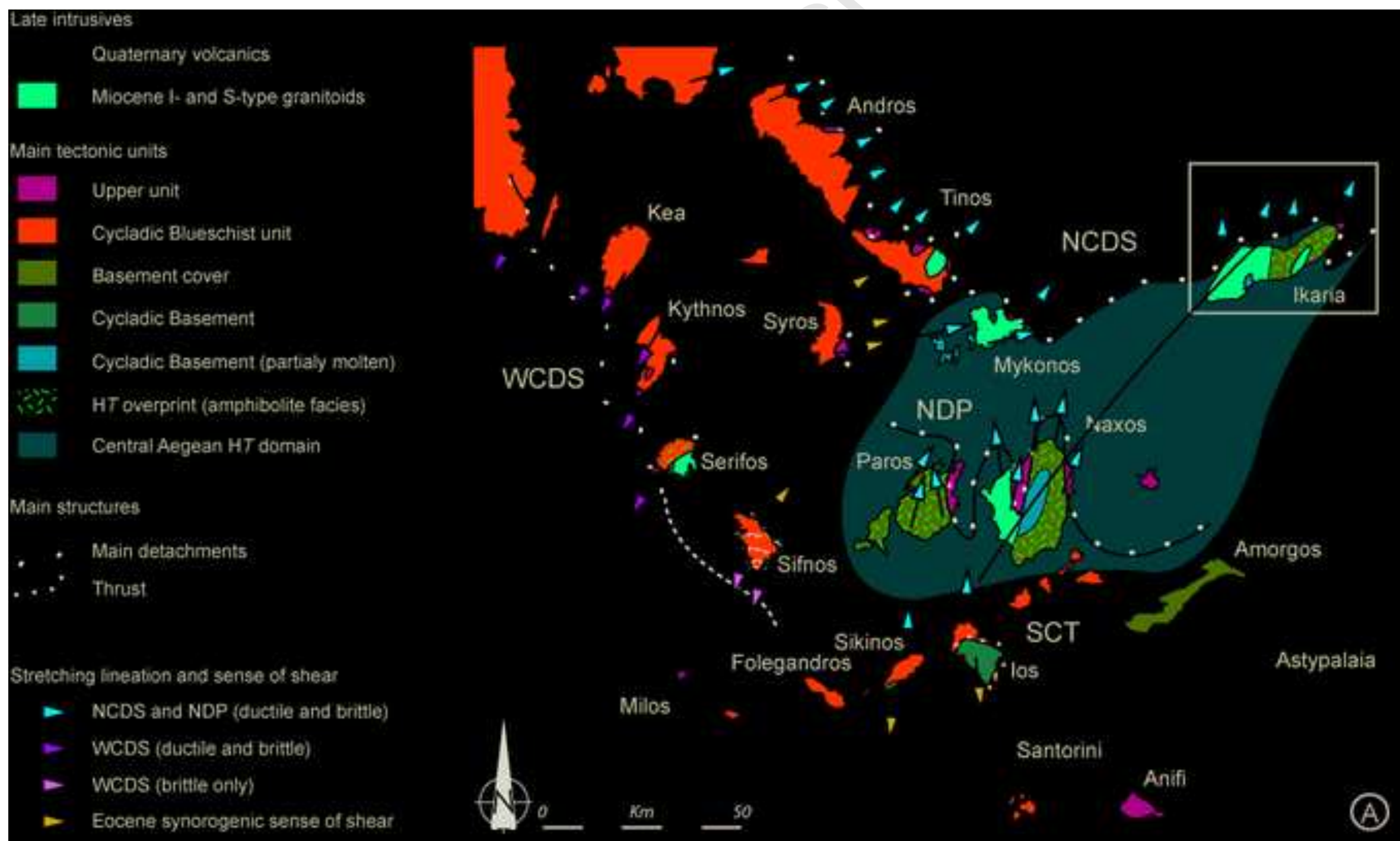

NE

NCDS Ikaria 


\begin{tabular}{|c|c|c|c|c|c|c|c|}
\hline \multirow[t]{2}{*}{ Sample } & \multicolumn{2}{|c|}{ Coordinates (UTM $35 \mathrm{~N}$ ) } & \multirow[t]{2}{*}{$\mathrm{n}$} & \multicolumn{2}{|c|}{$\mathrm{R} 2$} & \multicolumn{2}{|c|}{$\mathrm{T}\left({ }^{\circ} \mathrm{C}\right)$} \\
\hline & & & & Mean & SD & Mean & SD \\
\hline \multicolumn{8}{|c|}{ Agios-Kirykos unit } \\
\hline IK 12-15 & 441548 & 4168007 & 21 & 0,562 & 0,036 & 391 & 16 \\
\hline IK 13-33 & 438478 & 4163867 & 19 & 0,535 & 0,043 & 403 & 19 \\
\hline IK 13-31 & 438178 & 4163625 & 20 & 0,482 & 0,049 & 426 & 21 \\
\hline IK 13-34 & 438453 & 4164338 & 19 & 0,473 & 0,044 & 430 & 19 \\
\hline IK 12-13 & 439086 & 4164923 & 19 & 0,453 & 0,037 & 439 & 17 \\
\hline IK 13-22 & 440733 & 4168835 & 14 & 0,433 & 0,023 & 448 & 10 \\
\hline \multicolumn{8}{|l|}{ Ikaria unit } \\
\hline IK $13-28$ & 441898 & 4171296 & 19 & 0,312 & 0,049 & 502 & 22 \\
\hline IK 12-14 & 439237 & 4165283 & 20 & 0,303 & 0,082 & 506 & 36 \\
\hline IKS 13-13 & 428570 & 4164441 & 17 & 0,278 & 0,035 & 517 & 16 \\
\hline IKS 13-11 & 431485 & 4165492 & 21 & 0,269 & 0,104 & 521 & 46 \\
\hline IK 12-01 & 428758 & 4164611 & 23 & 0,266 & 0,051 & 522 & 22 \\
\hline IK $12-20$ & 427111 & 4163553 & 18 & 0,264 & 0,038 & 523 & 17 \\
\hline IK 13-29 & 442324 & 4170727 & 13 & 0,262 & 0,034 & 524 & 15 \\
\hline IK 13-35 & 438248 & 4164495 & 15 & 0,251 & 0,039 & 530 & 17 \\
\hline IK 13-27 & 441743 & 4170619 & 15 & 0,241 & 0,033 & 534 & 15 \\
\hline IK 13-07 & 426986 & 4160696 & 21 & 0,233 & 0,081 & 537 & 36 \\
\hline IKS 13-06 & 432513 & 4162583 & 16 & 0,228 & 0,029 & 540 & 13 \\
\hline IKS 13-03 & 424903 & 4158649 & 16 & 0,219 & 0,047 & 543 & 21 \\
\hline IK $12-12$ & 438723 & 4164980 & 20 & 0,216 & 0,082 & 545 & 37 \\
\hline IK 13-05 & 426436 & 4160041 & 15 & 0,216 & 0,055 & 545 & 24 \\
\hline IK 13-06 & 426795 & 4160494 & 16 & 0,213 & 0,065 & 546 & 29 \\
\hline IKS 13-12 & 427145 & 4161730 & 16 & 0,209 & 0,035 & 548 & 16 \\
\hline IK 12-04 & 426177 & 4165286 & 16 & 0,204 & 0,040 & 550 & 18 \\
\hline IK 13-08 & 425761 & 4165301 & 18 & 0,202 & 0,057 & 551 & 25 \\
\hline IK 12-21 & 425535 & 4161591 & 13 & 0,194 & 0,044 & 555 & 19 \\
\hline IK 12-11 & 438363 & 4165292 & 19 & 0,174 & 0,041 & 564 & 18 \\
\hline IKS 13-10 & 435557 & 4167534 & 13 & 0,130 & 0,042 & 583 & 19 \\
\hline IK 13-09 & 425573 & 4165499 & 17 & 0,129 & 0,045 & 584 & 20 \\
\hline IKS 13-04 & 430168 & 4161819 & 11 & 0,129 & 0,041 & 584 & 18 \\
\hline IKS 13-01 & 429434 & 4159919 & 17 & 0,110 & 0,051 & 592 & 23 \\
\hline IK $13-16$ & 440281 & 4168893 & 18 & 0,107 & 0,051 & 594 & 22 \\
\hline IK $13-13$ & 439031 & 4170692 & 15 & 0,083 & 0,040 & 604 & 18 \\
\hline IKS 13-14 & 427196 & 4158256 & 13 & 0,072 & 0,041 & 609 & 18 \\
\hline IKS 13-15 & 431859 & 4160264 & 14 & 0,054 & 0,045 & 617 & 20 \\
\hline IK 12-24 & 433322 & 4166192 & 18 & 0,037 & 0,034 & 625 & 15 \\
\hline
\end{tabular}




\section{Supplementary data (e-component)}

Click here to download Supplementary data (e-component): Th-U-Pb analyses.xls

Page 86 of 86 